أثر استخدام استراتيجية المناقشة في تنمية مهارات التفكير الإبلداعي في تدريس القرايرة للدى طلاب الصف الأول الثانوي العام.

\title{
إعراد الباحثئ
}

رمضان مصباح عبد القوى مصباح

$$
\begin{aligned}
& \text { إڤ إمرأ } \\
& \text { الدكتور } \\
& \text { محمدل عويس القرني } \\
& \text { مدرس المناهج وطرق التدريس الترني } \\
& \text { في كلية التزبية بجامعة الفيوم }
\end{aligned}
$$

\author{
الأستاذ الدكتور

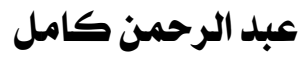 \\ أستاذ المناهج وطرق التدريس \\ في كلية التزبية بجامعة الفيوم
}

\section{ملخص البحث}

ويشتمل هذا الملخص على محورين هما:

أ- الإطار النظري للبحث: قام الباحث بعرض الإطار النظري للبحث فــي أربعـة

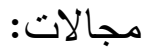

تتاول المجال الأول عرضيًا لخطة البحث متضمنًا مــشكلة البحــث، وفروضـــه، و أهدافه،، وحدوده، و أدو اته، ومصطلحاته، حيث كانت مشكلة البحث تتلخص فـي وجود ضعف لاى كثير من الطلاب في بعض مهار ات التفكير الإبــداعي، وعــدم القدرة توليد المعاني و التز اكيب إلا المذكورة في الكتاب المدرسي، فقد يفيد استخدام استر اتيجية المناقتنة في علاج ضعف الطلاب في القراعة، وربما ينمي استخدام هذه الإستر اتيجية بعض مهار ات التفكير الإبداعي لديهم؛ ومن ثم يحاول البحث الحـالي الإجابة عن السؤال الرئيس الآتي:

ما أثر استخدام إستراتيجية المناقشة في تدريس القــــراعة لتنميــة بعـض التض مهار ات التفكير الإبداعي لاى طلاب الصف الأول الثانوي العام ؟ وتقرع من هذا السؤال الأسئلة الفرعية الآتية: 


\section{العدد الحادي عشر ... الجزيه الأول}

1- ما مهار ات التفكير الإبداعي المناسبة لطلاب الصف الأول الثانوي العام ؟ Y- كيف يمكن إعداد وحدة مقترحة في القر اعة لتتمية مهار ات التفكيــر الإبـــداعي باستخدام إستر اتيجية المناقشة لدى طلاب الصف الأول الثانوي العام ؟ ب- ما أثر تدريس الوحدة المقترحة باستخدام استر اتيجيه المناقتـة في تتمية بعـض مهار ات التفكير الإبداعي لدى طلاب الصف الأول الثانوي العام؟

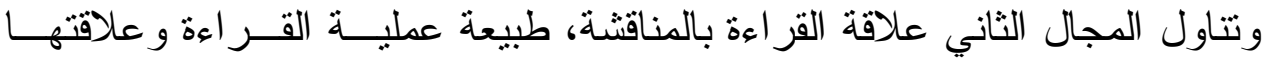

بالتفكير الإبداعي، كما تتاول أهمية تتمية مهار ات التفكيــر الإبــــاعي:(مفهومهــا، ووسـائل تتميــة مهــار ات التقكير الإبداعي) أما المجال الثالث تتاول استر اتيجية المناقثة: من حيث تعريفها، و أهميتها في التدريس و الممارسات التدريسية المتصلة

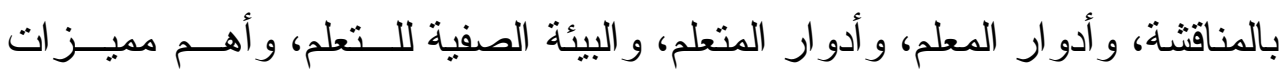
استر اتيجية المناقشة.

ب - الإطار التجريبي للبحث: قام الباحث بعرض النتائج للبحــث، وتقـسير هـــه النتائج، وحساب حجم التأثير •

أهم نتائج البحث: قام البحث بتتمية بعض مهار ات التقكير الإبداعي لدى عينة مــن طالبات الصف الأول الثانوي العام، وذللك باستخدام استر اتيجية المناقـشة، وكانــــ أهم نتائج هذا البحث، هي: - البات

1- استتناج مهار ات التفكير الإبداعي المناسبة لطلاب الصف الأول الثانوي العام. r- تفوقت المجموعة التجريبية على المجموعة الضابطة فـي الاختبــار البعـدي لمهار ات التفكير الإبداعي ككل.

ب- كما وجدت فروق ذات دلالة إحصائية عند مستوى 1 ., · و ه , • بين منوسطي درجات طالبات المجمو عتين التجريبية و الضابطة من حيث مهـــار ات التفكيـر (الطلاقة - الأصالة - المرونة- الحساسية للمشكلات) 
ع - ووجدت فروق ذات دلالة إحصائية عند مستوى ا ., · و ه , · بين منوسـطي درجات طالبات المجمو عتين التجريبية و الضـابطة من حيــث تــدريس القــر اءة باستر اتيجية المناقثة ج- التوصيات والبحوث المقترحة: أ- التوصيات والمقترحات: في ضوء نتائج البحث يتقدم الباحث ببعض التوصيات و المقترحات التي يرى أنها تقيد عند تتمية التفكير الإبداعي باســتخدام إبــتر اتيجية المناقنشة في تدريس موضو عات القر اءة:

- أن يستثر معلم اللغة العربية جميع فروع المادة لتتمية مهار ات القر اعة و التفكير

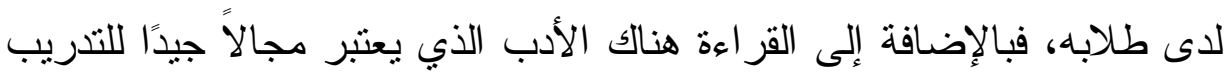

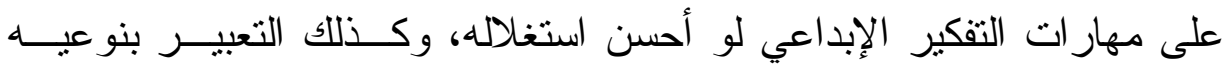
الثفوي و التحريري باعتبار أن موضوعات التعبير غالبًا مـــا تعكـس قـ فـايا اجتماعية وغير اجتماعية يدور حولها؛ مما يؤدي إلى التفاوض الاجتماعي بين ما تم تعلمه من قبل وما يمكن تطبيقه الآن. - العناية بتقويم الأداء القرائي للطلاب باستخدام اختبار ات مخصصة لهذا الغرض، ويمكن الاسترشاد - في إعدادها- باختبار مهار ات التفكير الإبداعي الذي قدمه البحث الحالي.

- الاهتمام بتوفير الوسائل و الأنشطة التعليمية، وعقد الندوات و المنــاظر ات التـي تسهم في تتمية مهار ات القر اعة و التفكير الإبداعي.

- تتجيع الطالب على تحليل ونقد ما يقر أ، و عدم قبوله للاروس المقرو عة لمجـرد أنه ورد في كتاب مطبوع. 


\section{العدد الحادي عشر .... الجززي الأول}

ب - البحوث المقترحة: في ضوء ما أسفرت عنه نتــائج البحـــث، وفــي ضــــــ التوصيات السابقة يقتر ح الباحث القيام بــالبحوث و الدر اســات المـستقبلية الآتيــة استكمالاً و استمر ارًا للبحث الحالي. لبنز - أثز استخدام استر اتيجية المناقثـة في تتميــة مهـــار ات التفكيــر الإبــــاعي فـي النصوص الثعرية.

- أثز دمج بعض استر اتيجيات المناقنتة في تدريس موضوعات النحو المختلفة. - أثز استخدام استر اتيجية المناقنتة في تتمية مهار ات التفكير العليــا فــي تــدريس البلاغة لدى طلاب الصف الأول الثانوي العام.

\section{الإحساس بمشكلة البحث:}

تعد اللغة من أهم الظو اهر الاجتماعية التي أنتجها العقــل البــشرى خــلهل

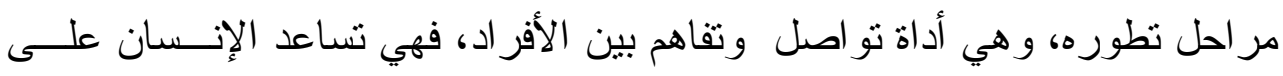
التفكير ، وبها يتعلم من الآخرين ويكتسب معارفه ومهار اته في العمل وفي العـيش في مجتمعه المحلى و العالمي (*)، لذلك فإن " القر اءة تعد من أهم المهار ات اللغوية، ومن أهم وسائل إمداد الفكر الإنساني بأسس الإبداع، إذ يعيش الإنسان بالقر اءة حياة

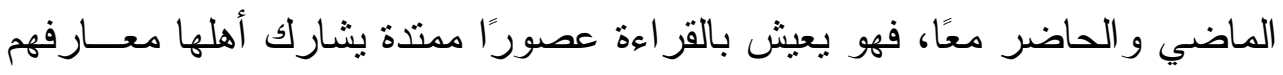

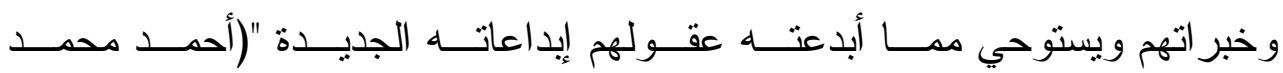
(المعتوق: (1997، (199)

وتبرز أهمية القر اءة من أهمية اللغة ذاتها فالقر اءة هي في الحقيقة تعبير، أدواتــهـ

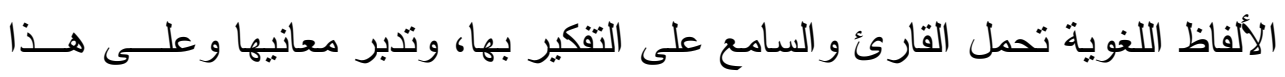
الأساس ظهر إتجاه دعا إليه المتخصصون في التعليم يؤكد على ضرورة تـضمين ولئ (*) يتم النوثيق على النحو النالي: اسم المؤلف أو الباحث، ثم اسم الدولة التي نثر فيها الكتاب، ثم سنة النشــر، ورقم الصفحة أو الصفحات التي تم الرجوع إليها. 
مهار ات التفكير في المناهج الدر اسية و العمل على تتميتهــا مــن خـــلد طر ائـق

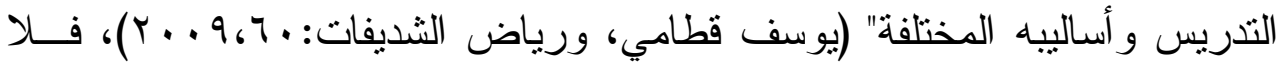
يمكن تتمية التفكير عند الطلاب ما لم يتعلمو اكيف يفكرون، وذلــــ عـن طريــق

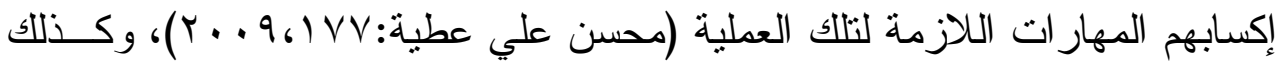
لأنه " من أهم أهداف تدريس القر اعة هو تتمية التفكير الإبداعي لدى كل من لديـــ

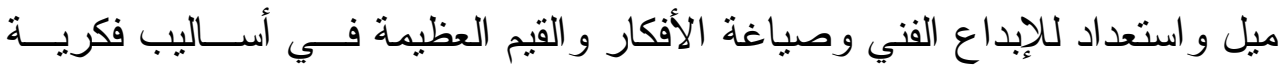

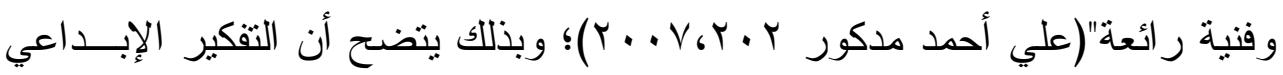
من الأهداف التربوية المهمة و الملحة التي يجب على كل مؤسسات التعليم أن تعمل

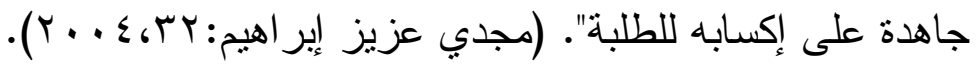

وتعد المناقشة من الطرق الفعالة في تدريس اللغة العربية، حيث تـسـاعد فـي تتمية معلومات الطلاب، وثروتهم اللغوية، وتحثهم على البحث و الإطلاع، وتكسبهم مهارة المناقشنة، وتعودهم التعبير عن آرائهم، وحسن عرض وجهة نظر هم، وتبادل

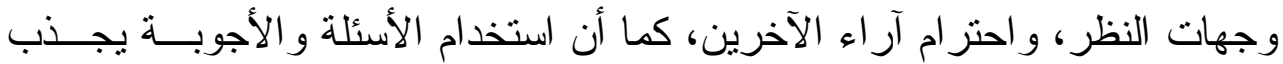
انتباه الطلاب نحو الدرس، ويشعر هم بأثز مساهمتهم في ســيره.(محمــود رشــدي

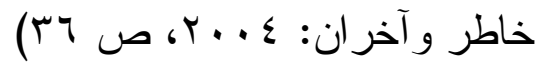

ولا تقتصر المناقتنة على موقفٍ دون آخر، بل تستخدم فـي كثبــرٍ مــن المو اقف داخل المدرسة وخارجها، فهنالك المناقثة التي تجري أثناء الزيار ات، ورعند تقديم الناس بعضهم لبعض، و على المو ائد العامة، و عند تلقــي المعلومــات، وفــي المؤتمرات، أو عند الخلاف في مسألة ما، أو عند وضع خطة للقيام بعمل ما. (علي

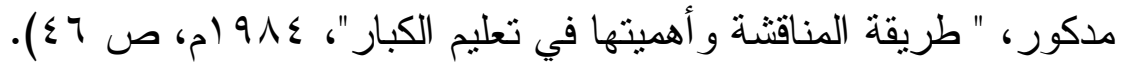
كما أن استر اتيجية المناقثة الصفية تعتمد على الحوار بين المعلم و المتعلِّين،

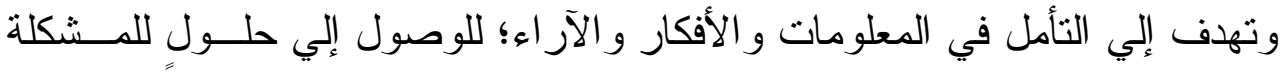
المطروحة، كما تستهدف نتمية المستويات العليا من التفكير : (كالتحليل، و التركيب، 


\section{العلد الحادي عشر .... الجزي الأول}

و التقويم، وغير ها)، فالمتعلِّم فيها لا يتلقى المعلومات بصورةٍ سلبية، بل هو منــاقش"

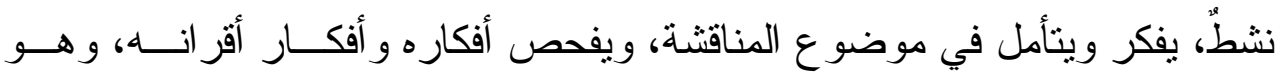
مستعدُّ لتغيير ر أيه إذا نبين له بالدليل الموضوعي ما يبرر ذلك التغيير .(عبد الحكيم

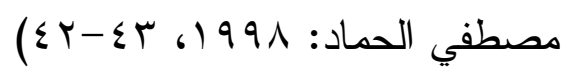

ورغم أهمية امتلاك الإنسان مهار ات التفكير الإبداعي، فإنه يوجــد قـصور فيهما لاى المتعلمّين، الأمر الذي توصل إليه الباحث من خلال عدة مصادر يمكـن تتاولها في الإحساس بمشكلة البحث.

وقد لاحظ الباحث وجود كثير من طلاب الصف الأول الثانوي العام يعـانون مــن الضعف في فهم كثيرٍ من المعاني اللغوية في سياقاتها المختلفة، وضعفهم فـي كثيــر

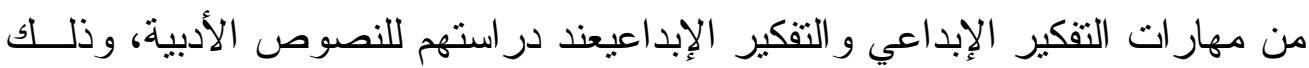
من خلال ما أيدته كثير من الدر اسات السابقة، وما لاحظه الباحث منها علــى ســبيل المثال لا الحصر منها الدر اسات الآتية: در اسة عبد الرحمن كامل ( (.... ب)، در اســـة

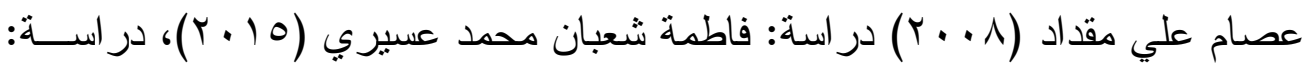
روتلاج،تايلر و أخرون Taylor \& Francis Group،Routledge (r ( • r)،در اسة

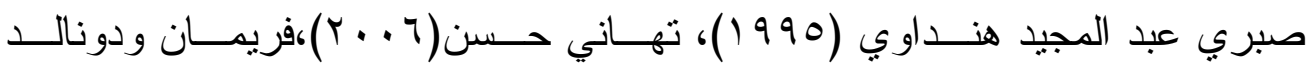
W.K(2011) Freeman Donald Penny ودر اسة كيرسان م.م)Crisan M.M (2013) عبد الوهاب،محمد محمــود

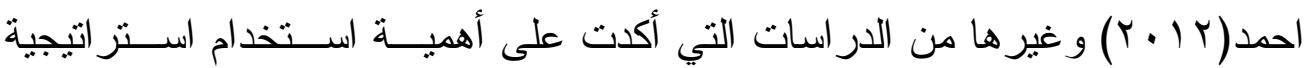
المناقتنة، وكذلك الدر اسات التي أيدت أهمية تتمية التقكير الإبداعي لطلاب المرحلـــة

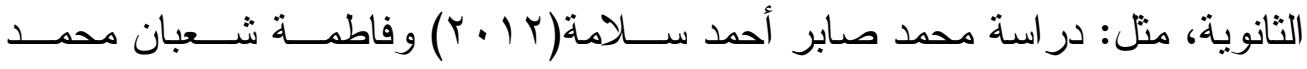

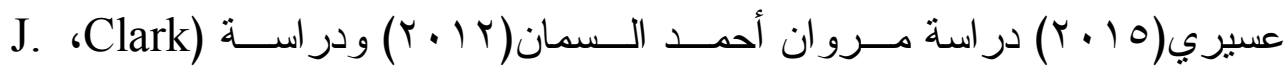

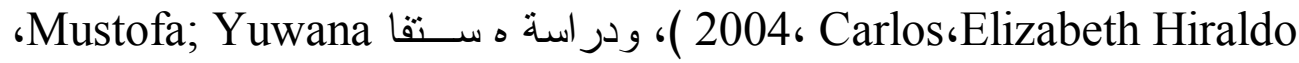
.H. Setya 2016 
وفي ضوء وُجد قصور في تنمية مهار ات التفكير الإبداعي من وجهة نظــر

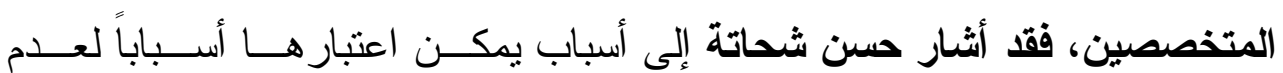

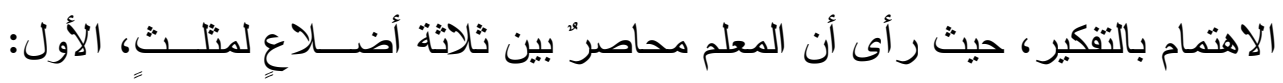

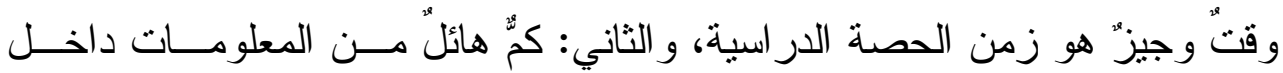

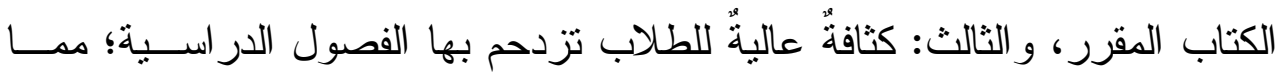

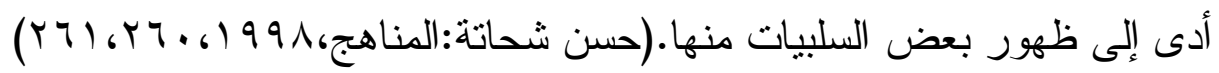
أ - قلة الجهود المبذولة في العملية التعليمية لتتمية مهار ات التفكير الإبداعي. ب- تركيز اهتمام الكثير من المعلمين على الانتهاء من مفردات المقرر باسـتخدام الطريقة الإلقائية، دون استخدام استر اتيجيات تدريسية تُمي التفكير .

ج- غياب كثير من الجو انب التطبيقية و الإبداعية من المناهج الحالية، وحل محلهــا التدريب الآلي على استجابات شرطية، و استلهام أسئلة الامتحانات القادمة من الامتحانات السابقة، دون النظر إلي أسئلة ذكية أو إبداعية.

د - اختز ال دور المتعلّم إلي الاستماع و النقل من السبورة، و غلبة الحفظ، و التزديــــ على التقاعل الإيجابي النشط؛ مما لا يساعد في تتمية التفكير الناقد، و التفكيـر

$$
\text { الإبداعي، وحل المشكلات. }
$$

فيلاحظ مما سبق وجود بعض السلبيات التي ترجع في معظمها إلى القـصور في استز اتيجيات التدريس المستخدمة، ذلك القصور الذي تبدو مظــاهره فـي

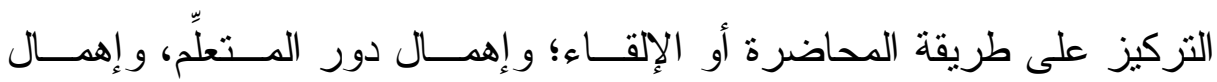

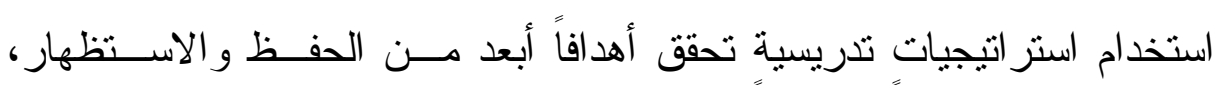
و إهمال تتمية مهار ات التقكير العليا.

فهذا يشير إلى إهمال تتمية مهار ات التفكير الإبداعي للاعتمــاد علــى ثقافــة الحفظ و الاستظهار لا على ثقافة الإبداع و الابتكار . 
وقد توصل وايتنجتون وزملاؤه(Whittington \& Others) فــي در اســة أجريت؛ لمعرفة مدى اهتمام المعلمين بتتمية مهار ات التفكير العليـا، إلــى أن اهتمامهم انصبَّ بصورة أساسيةٍ على مهار ات التفكير الدنيا من تصنيف بلـــوم: (التذكر و الفهم و التطبيق)، أمَّا المهار ات العليا: (التحليل و التزكيب و التقويم) فلم

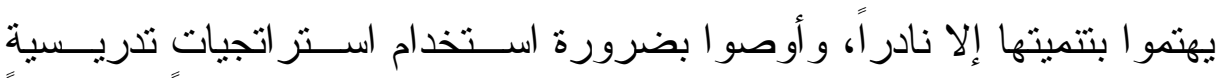
M. Whittington, Susie تعمل على تتمية تلك المستويات العليا من التقكيــر (and others, 2003, p613)

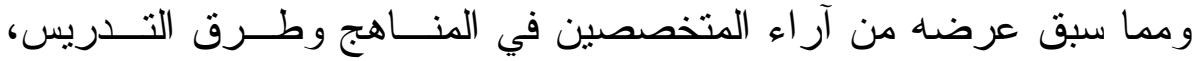
و المتخصصين في التفكير ، يتضح وجود قصور في مهار ات التفكير الإبداعي لــدى المتعلمين، يرجع إلى عدم استخدام استر اتيجيات تدريـسية تـــوفر البيئـة الــصفية المالأمة لتتمية مهار ات التفكير •

وتوجد در اساتُ عربيةٌٌ متعددةٌ (") في ميدان اللغة العربية وغيرها من المــو اد

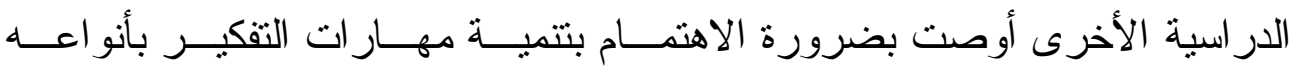
المتعددة:(ناقد -إبداعي - ابتكاري)، كما أوصت بأهميــة اســتخدام اســنز اتيجيات

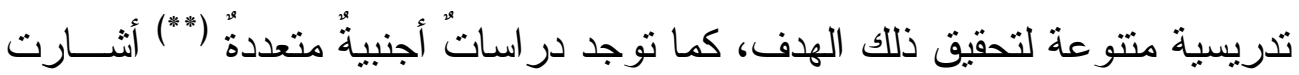
إلى أهمية التفكير بأنو اعه المتعددة وضرورة العمل على تتمية مهار اته.

(*) من هذه الدراسات: - أحمد محمد سيد: " فاعلية دداخل مقترحة لتتمية التفكير الإبداعي في الرياضيات لاعى طلاب المرحلة

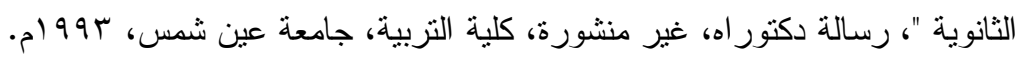

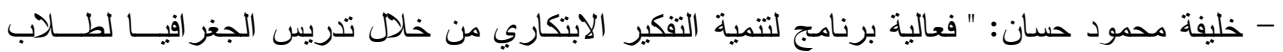

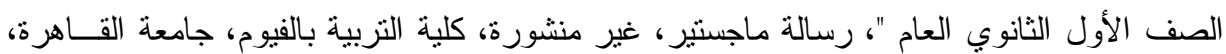

$$
\begin{aligned}
& \text { r. r r r } \\
& \text { (*** من هذه الدراسات: }
\end{aligned}
$$

J. Laurance, Splitter: Teaching For Higher Order Thinking Skills.

for higher Order http://www.chss.montclair.edu/inquiry/summ95/Splitter.html on the theme of.teaching (Thinking Skills 1), 15/04/2003 
لللك " فأن طريقة التدريس التي تعتمد على المناقشة و الحوار و إيداء الر أي لها

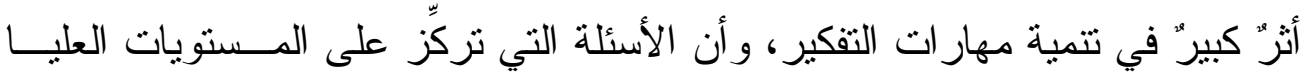

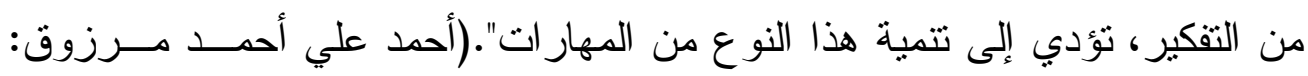
$(101-10.6191 \mathrm{~V}$

مما سبق عرضه من الدر اسات السابقة يتضح وجود قــصور فــي مهـار ات التفكير الإبداعي، ووجود قصور في استر اتيجيات تدريس القر اعة لتتميــة مهــار ات

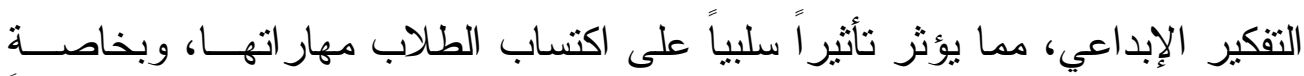
المهار ات المرتبطة بالمستويات العليا من التفكير، مما يستلزم تجريب اســتر اتيجيات متعددة لتتمية هذه المهار ات. كل ذلك حدا بالباحث استخدام إستر اتيجيات تدريسية تحقق أهدافًا أبعد من الحفـــ و الاستظهار، و البحث الحالي يهدف إلى تتمية بعض مهار ات التفكير الإبداعي لدى طلاب المرحلة الثانوية من خلال استخدام استر اتيجية المناقتشة. تحديا مشكلة البحث:

وفي ضوء ما تقدم يمكن تحديد مشكلة البحث الحالي الإجابة عن السؤال الــــئيس الآتي:

"ما أثز استخدام استراتيجية المناقشة في تدريس القراعة على تنمية بعـض مهارات التفكير الإبداعي لاى طلاب الصف الأول الثانوي العام"؟ ويتفرع من هذا السؤال الأسئلة الفرعية الآتية: 1- ما مهار ات التفكير الإبداعي المناسبة لطلاب الصف الأول الثانوي العام ؟ Y- كيف يمكن إعداد وحدة مقترحة في القر اعة لتتمية مهار ات التفكيــر الإبــداعي باستخدام إستر اتيجية المناقتة لدى طلاب الصف الأول الثانوي العام ؟ 
r- ما أثز تدريس الوحدة المقترحة باستخدام المناقتنة في تتمية بعــ مهــار ات

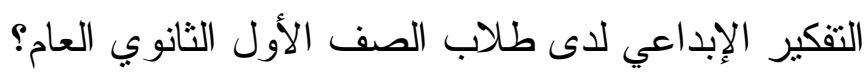
مصطلحات البحث:

ا- مهار ات التفكير الإبداعي: وقد تعددت التعريفات التي تتاولت التفكير الإبــــاعي

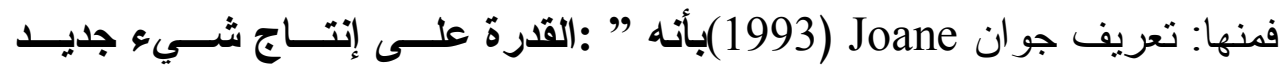
والخروج بمخزون من المعلومات التي ينتفع به.(Joane, P,5.(1993)

وعرفه فتحي جروان( 999 (بأنه "نشاط عقلي مركب و هادف توجهه رغبــة قوية في البحث عن حلول أو التوصل إلى نو اتج أصلية لم تكن معروفة سابقاً "(فتحي ركي

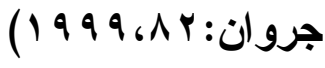

وعرفه عبد القادر الشيخلي بأنه " العملية التي تتضمن الإحساس بالمـشكلات

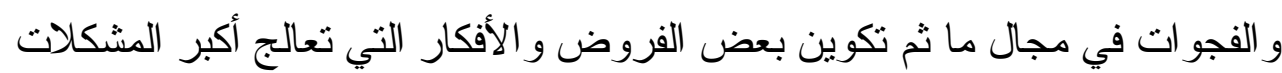
أو توصيل النتائج للآخرين (عبدالقادر الثيخلي Y . . Y،: ع . Y)، بينما عرفته لطفية عبدالشكور بأنه" نشاط عقلي مركب وهادف توجهه رغبه قويه في البحسـ عـن حلول أو التوصل إلي نواتج أصيلة لم تكن معروفة سابقا". (لطفية عبــــ الـشكور

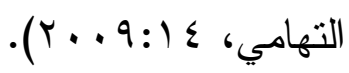

تعريف التفكير الإبـاعي إجرائيا: بأنه نشاط عقلي يتم فيه البحث عن حلول جديــدة غير مألوفة ومبتكرة لما يو اجهه الطالب من مشكلات أو مو اقف حياتية. r - استر اتيجية المناقشة:

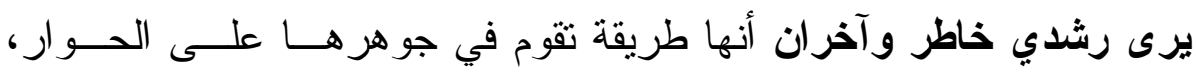

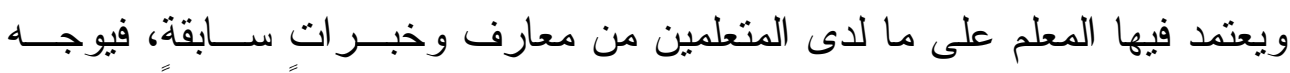

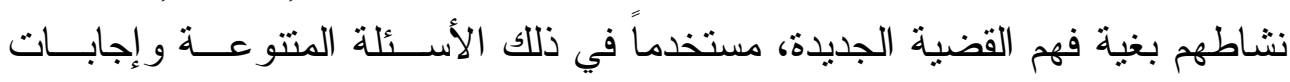

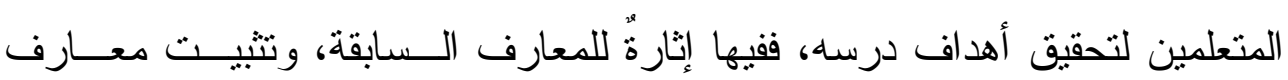


جديدة، و التأكد من فهم هذا وذاك، وفيها إثارةٌ للنشاط العقلي الفعال عندهم، وتتميــة انتباههم، وتأكيد تفكير هم المستقل. (محمود رشدي خــاطر و آخـر ان، الاتجاهــات الحديثة في تعليم اللغة العربية و التربية الدينية، ع^9 (م، ص سب).

ويرى عبد الحكيم حماد " أنها طريقة تدريسية تستهذف الكثف عن الحقـائق

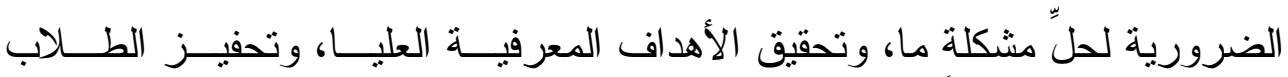
للمشاركة الفعالة في النقاش، وتوفير التعبير عن الر أي و احتر ام الر أي الآخر "(عبد التهن

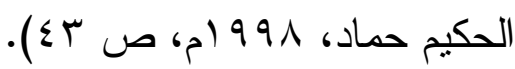

ويرى الباحث أن المناقثة تعدُّ جزءًا من كل الاستر اتيجيات التدريسية، وهــذا لا ينفي استقلالها و اختصاصها بمجموعة من الإجر اءات تشكلّ جوهر المناقشة كبنية خاصة داخل الصف. حدود البحث: اقتصر البحث الحالي على الحدود الآتية: 1- عينة من طلاب الصف الأول الثانوي العام في بعض المدارس الثانويـــة فـي

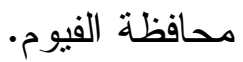

ץ- الالنز ام بالزمن المخصص لدروس القر اعة المقررة على طلاب الــصف الأول

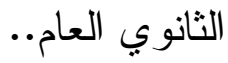

ب- يقتصر إعداد الوحدة على إعادة صباغة بعض موضو عات القــر اعة المقــررة على طلاب الصف الأول الثانوي العام في ضوء مهار ات التفكيــر الإبــــاعي المناسبة لطلاب الصف الأول الثانوي العام. أهمية البحث: قد يفيد هذا البحث في:

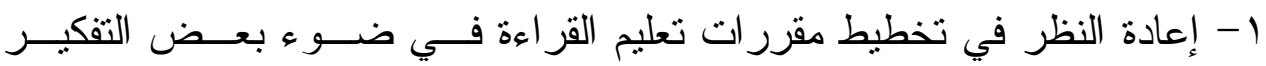
الإبداعي الو اجب تتميتها لدى الطلاب. 


\section{العدد الحادي عشر ... الجزئ الأول}

r- توجيه معلمي اللغة العربية بالمرحلة الثانوية فـي تعــرف كيفيـة اســتخدام إستر اتيجية حديثة في تدريس القر اعة لدى طلاب الصف الأول التـانوي العـام هي إستر اتيجية المناقشة. أدوات البحث: تثقسم أدوات البحث إلى ما يلي:

$$
\text { أ- أدوات قبياس: }
$$

1- استبيان لتحديد مهار ات التفكير الإبداعي المناسبة لدى طــلاب الــصف الأول الثانوي.

r- اختبار في بعض مهارات التفكير الإبداعي لاع طلاب الــصف الأول الثـانوى العام، وضبطه وبيان مدى موضوعيته. ب - أدوات تعليمبة وتثمل: 1- البرنامج المقترح في ضوء استر اتيجية المناقشة (كتيب الطالب). r - دليل المعلم لتدريس البرنامج المقترح. فروض البحث: سوف يختبر البحث الحالي الفروض الآتية: ا - لا يوجد فرق دال إحصائيًا بين متوســـي درجــات طــلاب المجمــوعتين التجريية والضابطة في التطبيق القبلي لاختبار بعض التفكير الإبداعي لــى الصف الأول الثانوي العام.

r- لا يوجد فرق دال إحصائيًا بين متوســـي درجــات طــلاب المجمــوعتين التجريبية و الضابطة في التطبيق البعدي لاختبار بعض التفكير الإبداعي لـدى الصف الأول الثانوي العام. أهداف البحث: يستهدف البحث الحالي: 
1- تتمية بعض مهار ات التفكير الإبداعي لدى طلاب الصف الأول الثانوي العام؛ مما يساهم في علاج أو الحد من ضعف هؤ لاء الطلاب في تلك المهار ات. r- الاهتمام بالمناقتنة- بكافة أنو اعها- كنظرية للتعليم و التعلم. خطوات البحث: سار البحث الحالي وفقاً للخطوات الآتية: - للإجابة عن السؤال الأول من أسئلة البحث وهو: ما مهارات التفكير الإبـــاعي المناسبة لطلاب الصف الأول الثانوي العام ؟ أعدَّ الباحث استبيانًا لتحديد مهار ات التفكير الإبداعي المناسـبـة لطــلاب الــصف

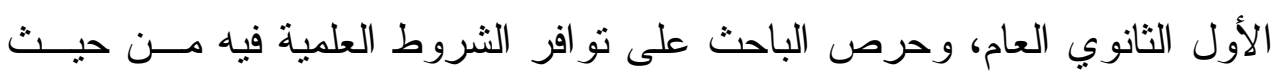

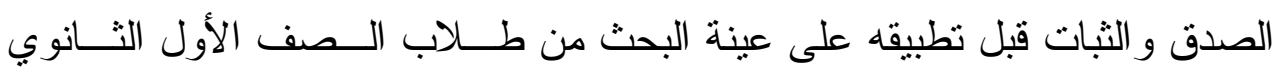
العام.

- للإجابة عن السؤال الثاني من أسئلة البحث وهو: كيف يمكـن إعــداد وحــدة مقترحة في القر اعة لتتمية مهار ات التفكيـر الإبـــاعي باســتخدام إســتر اتيجية المناقنة لدى طلاب الصف الأول الثانوي العام ؟

تم إعداد الوحدة المقترحة في ضوء المر اجع و الدر اســـات العلميــة الخاصـــة بإعداد الوحدات الدر اسية في ضوء إستر اتيجية المناقشة.

كما أعد الباحث دليلًا لتدريس الوحدة في ضوء إستر اتيجية المناقتنة، وتــدريب معلمي المجمو عة التجريبية على تدريسها.

كما تم إعداد اختبار في مهار ات التفكير الإبداعي لموضوعات القر اعة المقررة لاى طلاب عينة البحث، مع توخي إجر اءات الضبط العلمي. 


\section{العدد الحادي عشر ... الجززي الأول}

- وللإجابة عن السؤال الثالث من أسئلة البحث وهو: ما أثــر تــدريس الوحــدة المقترحة باستخدام إستر اتيجية المناقتة في تتمية بعض التفكير الإبـــاعي فـي تدريس موضوعات القر اعة المقررة لدى طلاب الصف الأول الثانوي العام؟

- تم تطبيق الاختبار الخاص بمهار ات التفكير الإبداعي على مجمـــوعتي البحــث

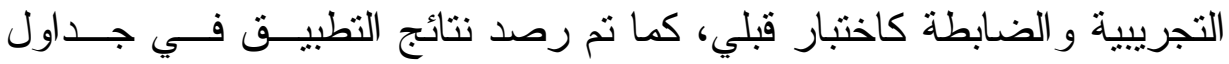
خاصة، وتحليلها وتفسير ها، كما تم تطبيق نفس الاختبار علــى طــلاب عينـــة البحث المجمو عتين التجريبية و الضابطة كاختبار بعـدي، وتــم رصــد نتــائج التطبيق في جداول خاصة، وتحليلها وتفسير ها.

- تم تقديم التوصيات و البحوث المقترحة في ضوء ما تم التوصل إليه من نتائج. وفيما يالي عرض موجز للإطار النظري للبحث:

1 - القراعة وعلاقتها بالتفكير الإبداعي: لا يمكن أن يكون الهدف الأساسـي مــن تعليم القراعة هو التذريب العضوي على النطق السليم، وزيادة الحــصيلة اللغويـــة فقط، بل يتعدى الهدف إلى مرحلة أوسع، وهى: تدريب الطالب على التفكير أثنــاء القر اعة، و الربط بين الأشياء، و التمبيز بينها، ثم يتعدى الهدف إلى مرحلـــة أعمــق،

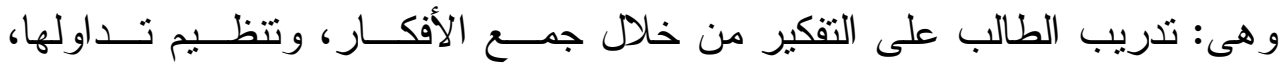

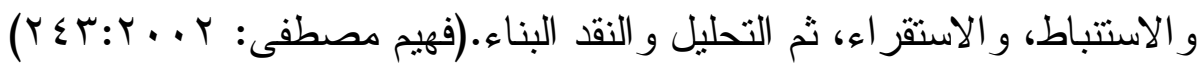

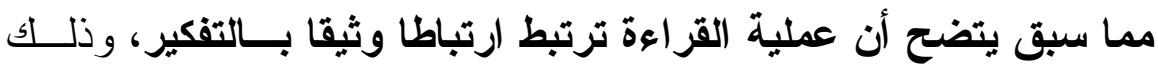
لأنها " عملية عقلية و عضوية و انفعالية، يتت من خلالها ترجمة الرمــوز المكتوبـــة بقدد التعرف عليها ونطقها، وفهمها ونقدها، و الاستفادة منها في حل المشكلات. وكذلك فإن" فهم المقروء: يعد عملية تفكير أساسية من عمليات القر اءة؛ بل عدّه البعض متضمنًا لكل ما تضمنته القر اعة من عمليــات ومهـــار ات " (إبــر اهيم

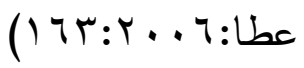


و القر اعة الفعّالة نتطلب سلسلة منطقية من أنماط التفكيــر ، وهـــهـ الأنمــاط

تحتاج إلى ممارسة وتمرين لتنتتها في العقل، وهذه (مر احل القر اءة) تــنلخص فـي العمليات السبع الأساسية التالية:

$$
\text { 1- التمبيز معرفة القارئ للرموز الأبجدية (الأحرف). }
$$

ب- التكامل الداخلي الأساسي المستخلص من المقروءة، معتمدا بشكل ضئيل علـى الخبر ات السابقة و التي لها علاقة بالقو اعد و المفردات اللغوية.

ع - التكامل الخارجي: التحليل و النقد و التقدير و الاختيار و الرفض، هــذه نــشاطات تتطلب من القارئ الرجوع إلى التجارب و الخبرات السابقة للتأثر على المهمة.

0- الاحتفاظ: هي القدرة على تخزين معلومات الذاكرة.

7- الاستدعاء (التذكر): القدرة على استعادة المعلومات من الذاكرة.

V- الاتصال: وهو يمثل تطبيق المعلومات ويصنف الاتصال على أربعة أصناف:

$$
\text { اتصال مكتوب. }
$$

اتصال من خلال الرسم و الكتابة و التلاعب بالأشكال و الأجسام.

التفكير : وهو عبارة تعبير عن أخر للاتصـال مع الــفنس" (كمــال

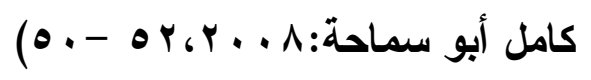

ومما سبق يتضتح من طبيعة عملية القر اعة ارتباطها بالتفكير؛ لإنها عمليـــة عقليــة و عضوية و انفعالية يتم من خلالها ترجمة الرموز المكتوبة بقصد التعـرف عليهـا و ونطقها، وفهمها ونقدها، و الاستفادة منها في حل المشكلات، كما أنها تتطلب تو ازنـــا عقليا و نفسيا وجسميا. 


\section{العلد الحادي عشر .... الجزي الأول}

- أهداف تدريس القراعة في المرحلة الثانوية: تتبو أ المرحلـــة الثانويـــة مكانـــة متميزة، وسامية في السلم التعليمي، حيث تعد بمنزلة حلقة الوصل بين التعلــيم

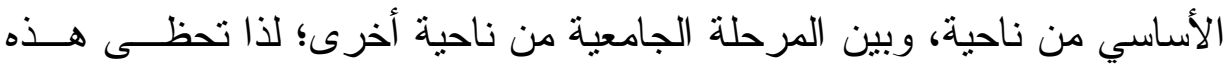
المرحلة خاصة باهتمام كبير من حيث البيئة و الفلسفة و إعداد الطالــبـ إعــدادا مثاليا يعود بالنفع على الفرد و المجتمع (فايزة السيد محمد عوض، محمد الـسيد

$$
\text { (حمد سعيد: r. ( }
$$

"وقد حدد " تيلور" في معرض در اسة قامت بها رابطة التعليم التقـدمي فـي أمريكا أهداف تعليم القر اعة في المرحلة الثانوية وهذه الأهداف هي:

إتقان مهار ات القر اءة، وتعرف صور ها المختلفة، و الميل إلى القر اعة ابتغـــاء

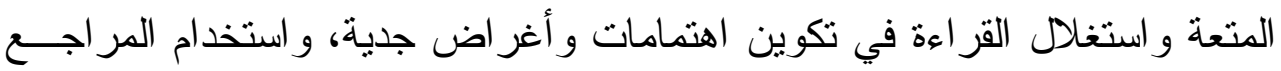

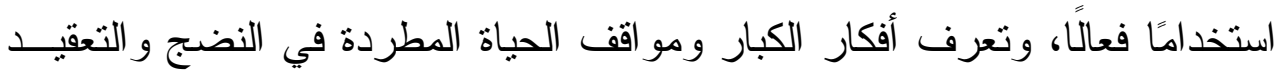
و العمق و المدى، و التعرف على المؤلفين أو بعض الثخصيات في الأدب و الــسير الذاتية، و استخدام القر اعة لتكوين أحكام منزنة، و استخدام القراعة في حل المشكلات

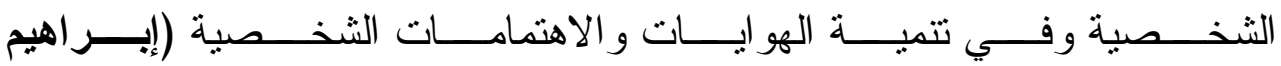
(IVY:Y.. T

وأثنار رشدي طعيمة ومحمد منـاع إلى أن" القر اعة بمختلــف أنو اعهـــا فـي المرحلة الثانوية تهدف إلى: 1- رفع مستوى المعلومات الاجتماعية للطلاب. r- صقل أذو اق الطلاب، و إثارة ميولهم، وشغفهم بالقر اعة.

r- تكوين شخصيات متكاملة حساسة قادرة على استخدام خبر ات الأجيال الماضية في سبيل حياة أفضل.(رشدي طعيمة ومحمد الــسيد منــاع: مرجـع ســابق،

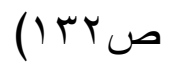


و أوضح علي مدكور أن أهداف تدريس القر اعة في المرحلة الثانوية نتمثل في:

ا - توســيع خــبر ات التلاميذ، و إغنـــاؤها عن طريــق القــر اءة الو اســعة فـي

$$
\text { المجــالات المتعددة. }
$$

ب- نتمية التربية الإسلامية، و النز عة الجمالية لدى الطلاب، وتزقية أذو اقهم. ب- تكوين عادات القر اعة للاستماع أو الدر اسة و البحث أو لحل المشكلات. ع- تتمية قدر ات ومهار ات القر اعة منثل السرعة في النظــر ، و الاستبــصار فـي القر اعتين الصامنة و الجهرية، بالإضافة إلى النطق في القراءة الجهرية. ه- قدرة الطلاب على تحليل وتقسير المادة المقرؤة، ونقدها، وتقويمها، ثم قبولها، أو رفهـا.

ج- تذريب الطلاب على استخدام المر اجع عن مو اد القراعة المناسبة، وتــدريبهم على ارتياد المكتبات تذريب الطلاب على مهارة الكثف في بعــض المعــاجم اللغوية التي تفي بحاجتهم

من خلل ما سبق عرضه يمكن تلخيص أهداف القزاعة في المرحلة الثانوية بما يلي: ا - تتمية حصبلة الطالب من الثروة اللغوية و التر اكيب الجيدة و الجديدة. r- تتمية القدرة على القر اعة بنو عيها الصامتة و الجهرية. ب- تدريب الطلاب على مهارة الكثف في المعاجم اللغوية لتفي بحاجتهم وتمدهم بالثروة اللغوية.

ع - تتمية قدرة الطالب على القر اعة في سلامة و انطلاق وفهم، و على التمبيز بــين الأفكار الجوهرية و العرضية فيما بقرؤه، و على فهم الأفكار الضمنية. 


\section{العدد الحادي عشر ... الجززي الأول}

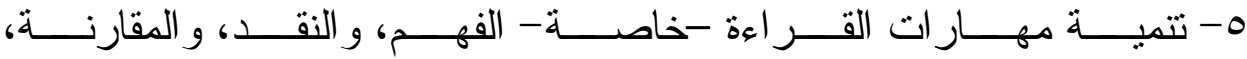
و الاستنتاجهو التحليل، و التقويم.

7- ربط الطلاب بالقضايا المعاصرة و الأحداث الجارية، وتدريبهم على تقييمهــا و الحكم عليها. V - تهذيب أذواق الطلاب وتتمية الحس الجمالي لديهم. ᄉ- نتمية القيم لخلقية التي تثبت تفوق الإنسان العربي المسلم 9- تتمية ميول الطلاب إلى القراعة، و انتقاء المادة المقرؤة الصالحة للقر اعة. • 1 - رفع مستوى المعلومات و الخبر ات و المفاهيم لدى الطلاب. 11 r

تعتمد المناقتة على الاثتر الك في فهم، وتحليل، وتقسير ، وتقويم موضوعٍ، أو فكرة، أو مشكلةٍ ما، وبيان مو اطن الاتفاق، ومو اطن الاختلاف فيها، وهي تعتبر

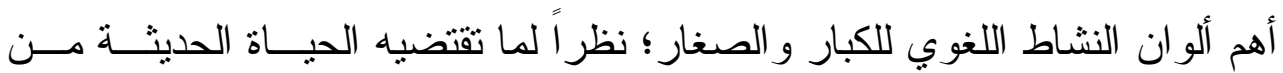

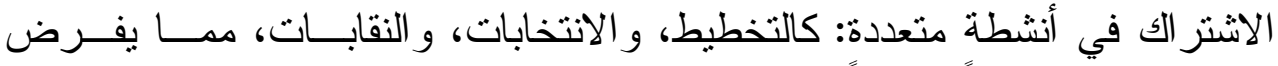

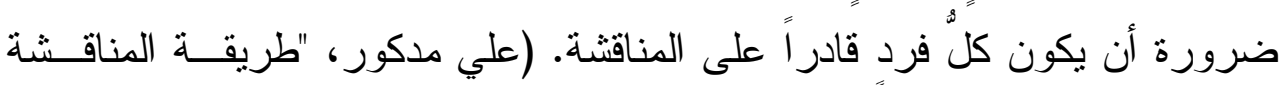

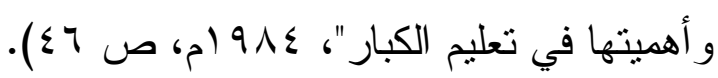

يرى رشدي خاطر وآخران أنها طريقة تقوم في جوهر ها علــى الحـــوار،

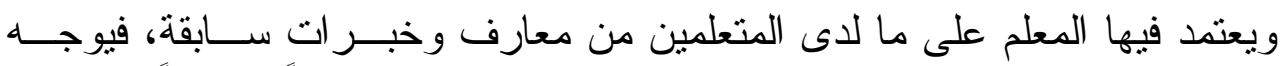
نشاطهم بغية فهم القضية الجديدة، مستخدماً في ذلك الأســئلة المتتوعـــة و إجابــات

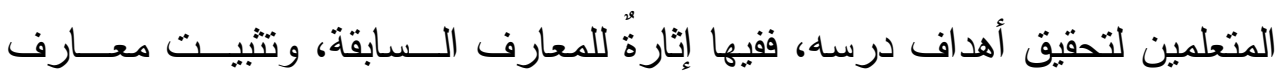
جديدة، وفيها إثارةٌ للنشاط العقلي الفعال عندهم، وتتمية انتباههم، وتأكيــــ تفكيــر هم 
المستقل. (محمود رشدي خاطر و آخران، الاتجاهات الحديثة في تعليم اللغة العربية

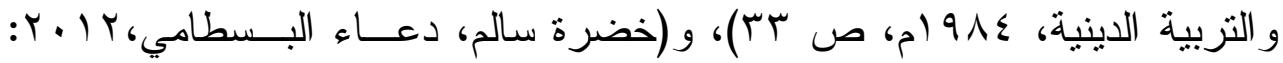

ويرى عبد الحكيم حماد " أنها طريقة تدريسـية تـستهدف الكـشف عـنـ الحقائق الضرورية لحلِّ مشكلة ما، وتحقيق الأهداف المعرفيــة العليــا، وتحفيــز فئز

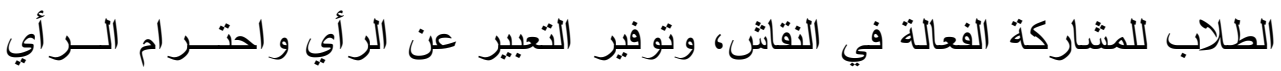
الآخر ".(عبد الحكيم حماد، 991 (:rع).

ويرى محمد عبد القادر أحمد أنها طريقةٌ " يقوم فيها التلامبذ بتحضير مادة

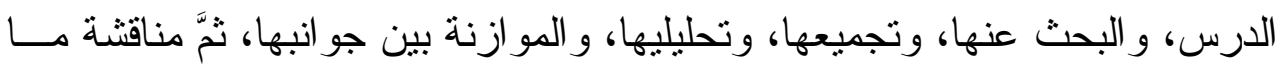

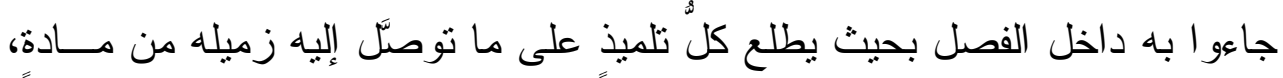
وبحثٍ و استقصاء، وبذلك يشترك جميع التلاميذ في إعداد الدرس، ويتعاونون فـي تجميع مادته " (محمد عبد القادر أحمد •99 19: 74 ()).

ويرى الباحث أن هذا التعريف يقترب بالمناقثة من طريقة البحث الجماعي

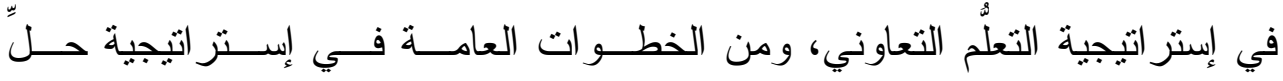

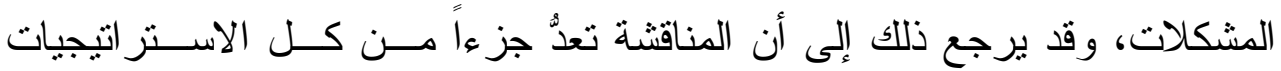

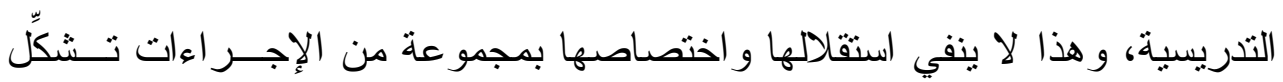
جوهر المناقشة كبنية خاصة داخل الصف.

وفي ضوء ما سبق فإنه يمكن تعريف المناقثة بأنها إستر اتيجية تدريسـية

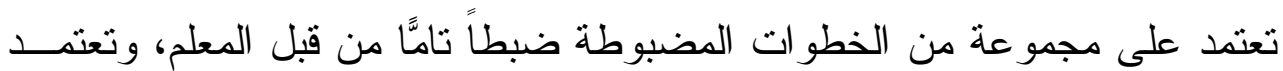
على التفاعل اللفظي النشط القائم على الحوار بين المعلم وطلابه من خلال سلـسلة من الأسئلة ذات مستوى معرفيٍٍ عال.

التتفكير الإبداعي: يُعَدّ التفكير الإبداعي نمطاً من أنماط التفكير المركب، وهو يمنل عملية نشاط ذهني ويعد أرقى أنماط التقكير ، وهي ظاهرة ذهنية متقدمة بعالج مــن 


\section{العدد الحادي عشر .... الجزئ الأول}

خلالها الفرد المو اقف، و المشكلات بطريقة فريدة، أو غيــر مألوفــة، أو بوضــع

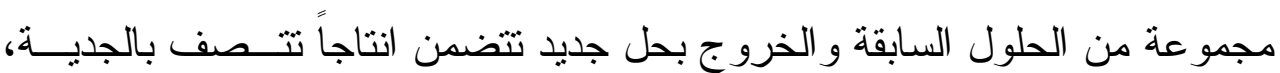
و الأصالة، ويتضمن إيجاد حلول للأفكار ، و المشكلات، وكذلك إنتاجاً جديداً و أصيلاً ذا قيمة للفرد و الجماعة، وأن الاهتمام بتعليم بالتفكير، هو في الأساس لتتمية الإبداع

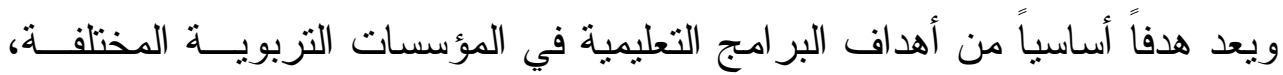

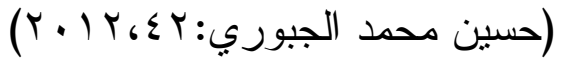

$$
\begin{aligned}
& \text { تعريف التفكير الإبداعي: }
\end{aligned}
$$

عرفه تور انس Torrance بأنه " عملية تحسس للمشكلات والــوعي بهـــا وبمواطن الضعف، والفجوات، والتنافر، والنقص فيها، وصياغة فرضيات جديدة، والتوصل إلى ارتباطات جديدة باستخدام المعلومات المتوافرة والبحث عن حلول،

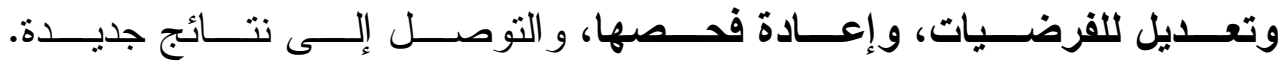
(Torrance,1963,p22) قوية في البحث عن حلول أو التوصل إلى نتائج أصيلة لم تكن معروفــة ســابقاً

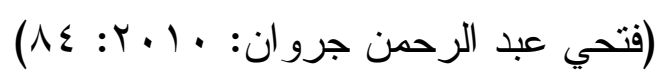

بينما يعرفه اللقاني و الجمل بأنه" عملية عقلية يمر بها الطالــبـ بمراحـلـ

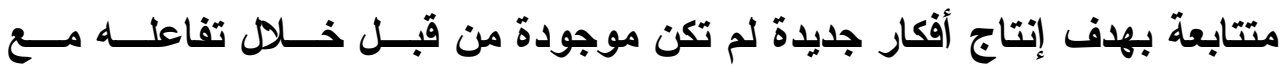

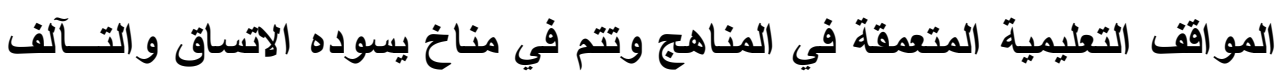

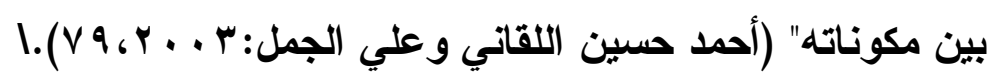


إن مر اجعةً لأكثر اختبار ات التفكير الإبـــداعي شــيو عاً، وهــــي اختبــار ات تورنس، و اختبار ات جيلفورد تشير إلى أهم مهار ات التفكير الإبــداعي، أو قدر اتــهـ الته التي حاول الباحثون قياسها، وهي:

أولاً: الطلاقة: Fluency وتعني "القدرة على توليد عدد كبيـر مــن البـــائل، أو المتر ادفات، أو الأفكار، أو المشكلات، أو الاستعمالات عند الاستجابة لمثير معين، و السر عة و السهولة في توليدها. وهي في جو هر ها عملية تذكر و استذعاء اختياريـــة

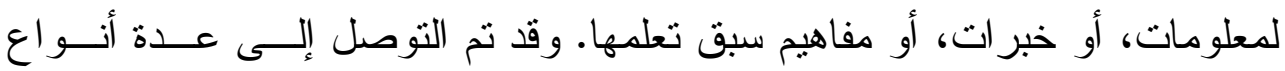

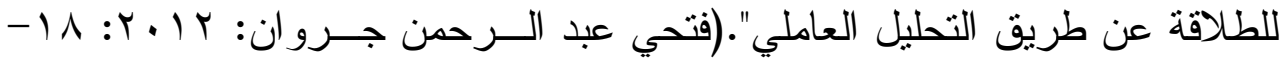

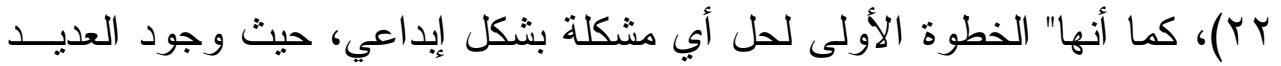

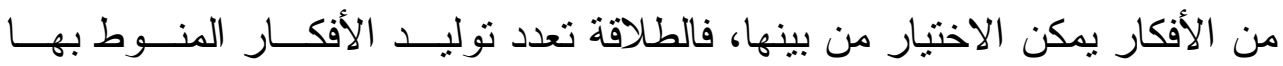
(Shively. C. H. (2011),p177) الوقوف على حل للمشكلة) وفي ما يلي تفصيل لهذه الأنواع مع أمثلة عليها:

أ. الطلاقة اللفظية أو طلاقة الكلمات، مثل:Verbual Fluency - اكتب أكبر عدد ممكن من الكلمات التي تبدأ بحرف "م" وتتتهي بحرف "م". ب. طلاقة المعاني أو الطلاقة الفكرية، مثل: Associational Fluency - اذكر كل النتائج المترنبة على زيادة عدد السكان بمقدار الضعفين. - أعط أكبر عدد ممكن من العناوين المناسبة لموضوع القصة..... جـ. طلاقة الأشكال والتعبير ات:Expressional Fluency : - وهي القدرة على ذكر عدد كبير من التفصيلات، أو التعديلات. ثانياً: المرونة:Flexibility : وهي القدرة على توليد أفكار منتوعة ليست من نوع

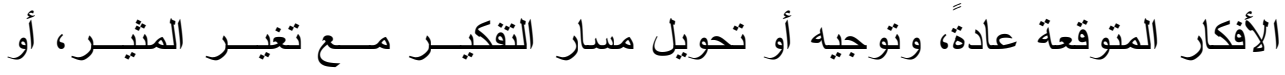




\section{العلد الحادي عشر .... الجزي الأول}

متطلبات الموقف. و المرونة هي عكس الجمود الذهني الذي يعني تبني أنماط ذهنية محددة سلفاً وغير قابلة للتغير حسب ما تستدعي الحاجة، ومن أثــــال المرونـــة: المرونة التلقائية، و المرونة التكيفية، ومرونة إعادة التعريف أو التخلي عن مفهــوم أو علاقة قديمة لمعالجة مشكلة جديدة، ومن الأمتلة عليها: - اكتب مقالاً قصير اً لا يحتوي على أي فعل ماض. - فكر في جميع الطرق التي يمكن أن تصممها لوزن الأثياء الخفيفة جداً. ويلاحظ هنا أن الاهتمام ينصب على تتوع الأفكار أو الاستجابات بينمـــا يتركــز الاهتمام بالنسبة للطلاقة على الكم دون الكيف و التتوع.

ثالثاً: الأصــالة: Originality: الأصـالة هي أكثر الخصائص ارتباطــاً بالإبــداع و التفكير الإبداعي، و الأصالة هنا بمعنى الجدة و التقرد، وهي العامل المشترك بــين معظم التعريفات التي تزكز على النواتج الإبداعية كمحك للحكــم علـى مسـستوى

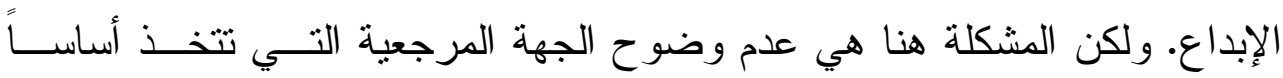

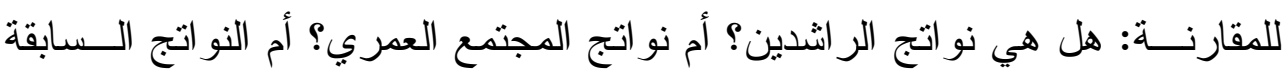
للفرد نفسـ؟

\section{رابعاً: الحساسية للمشكلات Sensitivity to problems}

ويقصد بها الوعي بوجود مشكلات أو حاجات أو عناصر ضعف فـي البيأـــة أو الموقف. ويعني ذلك أن بعض الأفر اد أسرع من غير هم فـي ملاحظـــة المــشكلة و التحقق من وجودها في الموقف.

و لا شك في أن اكتثاف المشكلة يمثل خطوة أولى في عملية البحث عن حل لهــا،

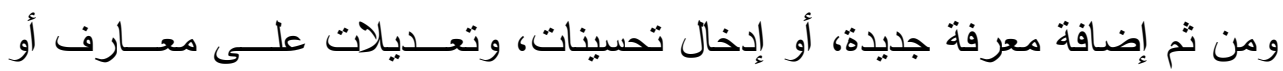

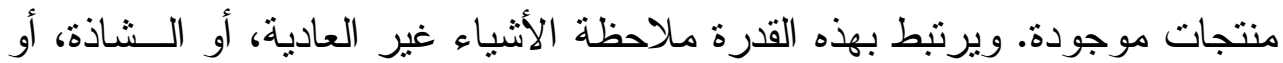
المحيرة في محيط الفرد، أو إعـادة توظيفهــا أو اســتخدامها و إتــارة تـساؤ لات 


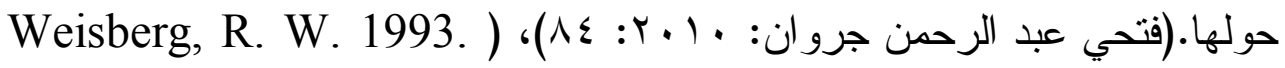
(pp.148-176

\section{طرق تعليم التفكير الإبداعي ضمن المو اد الار اسبة:}

تستخدم طرق عديدة لتعليم التفكير، وقد أورد عبـــ الله التـــافع (عبــــ الله

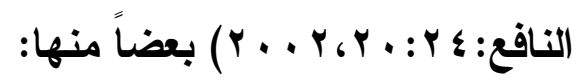

1 - إستر اتيجية الأسئلة المفتوحة:-

أ. -تتطلب الأسئلة المفتوحة النهائية.

ب.-- وهي أسئلة لها أكثر من إجابة.

ج.-وهي أسئلة تستثير التفكير.

كيفية تظوير إستر اتيجية الأسئلة المفتوحة في الارس:

أ. - التفكير في الأسئلة وكتابتها قبل بداية الدرس.

ب. - عرض الأسئلة في مكان بارز في الصف.

ج.-مناقثنة مفهوم الأسئلة المفتوحة مع الطلبة.

د. - تتويع الأسئلة لتتضمن نظاماً متدرجاً في مستوى مهار ات التفكير .

r - إستر اتيجية الأسئلة الممتدة (أي الأسئلة السابرة):

أ.--وتستخدم عندما يطلب المعلم من الطالب معلومات إيـضاحية عـنـ

إجاباته مستخدماً تلك العبار ات:

$$
\text { ج.--وضّح إجابتك. (أسلوب التوضيح) }
$$

د. -اثشرح أكثر وفصِّل في الإجابة. (أسلوب الاستفاضة) 


$$
\text { - ماذا تعني ب..... - ماذ - }
$$

- إجابتك ليست و اضحة، وضح أكثر !

- اشر ح ماذا تعني عندما تقول........... - هل هناك طريقة أخرى للتعبير عن ذلك. وأمثلة أسئلة التدعيم:

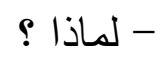$$
\text { - ما دلبلك ؟ }
$$

- ما استز اتيجيتك ؟

- كيف قررت ذلك ؟

- ما الإفادة التي لديك ؟

- ما الذي جعلك تصل إلى هذه النتيجة ؟

- اذكر ما يؤيد إجابتلك من نصوص الكتاب ؟

وأمثنة أسئلة الاستفاضة:

- كيف يكون ذللك ؟

- ماذا يحدث لو .... ؟

- ما الجزء المفقود ؟

$$
\text { - اشر ح أكثر - }
$$

r- إستر اتيجية تقبل الإجابة: 
أ- يسأل المعلم أكثر من طالب و احد للإجابة عن السؤال الواحد، ويتأكد من أن أكثر الطلاب لديهم الفرصة للإجابة.

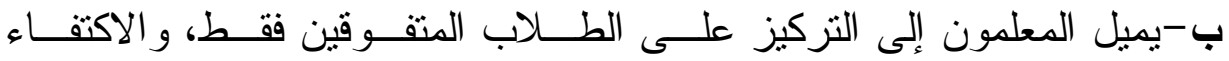
بإجاباتهم، ويهمل الطلاب البطيئين في الإجابة.

ج-يطلب المعلم إجابات متعددة،ويتوقف عن التعليــق عليهــا إلا بــالقبول أي تعزيز الإجابة.

د - عندما يتقبل المعلم أجوبة منتوعة فذلك يشجع زيادة في المشاركة من غالبية الطلاب. ه- تتوع الإجابات يسهم في إثارة التفكير. تطوير إستر اتيجية تقبل الإجابة: أ- سجل إجابات الطلاب، إما بالمسجلة، أو كتابتها على السبورة. ب - شجع الطلاب على المشاركة في المناقشة. ج- أخبر الطلاب بأنك سنطلب من كل طالب الإجابة بصرف النظر عن رفـع اليد.

د - قبل استدعاء الإجابة، اطلب من الطلاب كتابة الإجابة لديهم على كر اسات خاصة.

استخدم أساليب متنوعة لطلب الإجابة مثل:

$$
\begin{aligned}
& \text { أ- قدم حلًا آخر ؟ } \\
& \text { ب - قدم بديلًا آخر ؟ } \\
& \text { ج- أعرض طرقًا أخرى ؟ }
\end{aligned}
$$




\section{العلد الحادي عشر .... الجزي الأول}

د - تحفظ على إصدار حكم على إجابة الطالب عندما يخطئ؛ لأن المهم تعزيـز الإجابة الصحيحة، وليس السخرية من إجابة المتعلم.

- ابدأ بإستر اتيجية واحدة أو اثنتين يمكنك تبنيها بسهولة. - أضف بعد ذلــك إســتر اتيجيات أخــرى حتـى تــتمكن مــن تبنــي كـل الإستر اتيجيات".

وفي ضو ء ما سبق يمكن استخلاص بعض مهار ات التفكير الإبداعي التـي

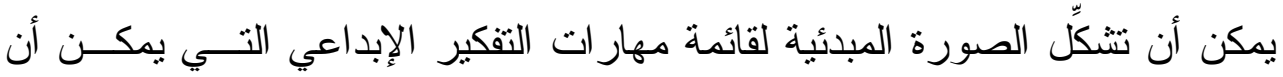
تذمج في تدريس القر اءة وهي:

Flexibility المرونة

Fluency الطلاقة

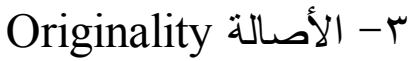

Sensitivity to problems ك- الحساسية للمشكلات

أدوار المعلمين في تنمية مهار ات التفكير الإبداعي: من تلك الأدوار ما يلي: بعد أن صـار تعليم التفكير الإبداعي مسئولية المعلم وضرورة تدريبه على ترجمــة الإبداع إلى ممارسات صفية، وذلك عن طريق المعرفة الجيدة و الفهم بنمو الطفـلـ، وخلق البيئة التعليمية المنتجة و المشجعة و المثيرة للإبـــداع، و اســتخدام التكنيكــات المناسبة و الثاملة لعملية تفاعل المعلم مع طلابه، وتتمية قدر اتهم على التـشخيص الدقيق لقدر ات المتعلمين. (Carter, M.:1992,p42) فقد صـار بإمكان المعلم تتمية التفكير الإبداعي لدى المتعلمين مــن خــلال تقــديم مشاريع لهم تتطلب خططاً ذهنية وتتفيذية، وتشجيع الطلاب عند محاولتهم اسـتخدام قدر اتهم العقلية، وتقديم تغذية راجعة، وجعل التعاون مدخلاً أساسياً في تتمية التفكير 1987,p42-47 (Rosenblum - cale, Karen.الإبداعي 


\section{ع - دور المعلم المبدع فيما يلي:}

تهيئة المو اقف التي تتطلب من الطلاب ممارســـة نـشـاط التفكيـر ولــــ إثنغالهم في البحث عن إجابة صحيحة لكل سؤال.

خلق بيئة صفية يتم تقبل أفكار المتعلمين، ودعوتهم للتعبير عـن أفكـار هم و معتقداتهم.

تشجيع المعلم للطلاب على نوليد عد كيير من الأفكار، و للسرعة ولـسهولة فـي

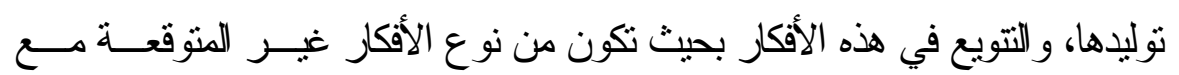
الحفاظ على اللثرد، و الجدة، لأفكار كل طالب.

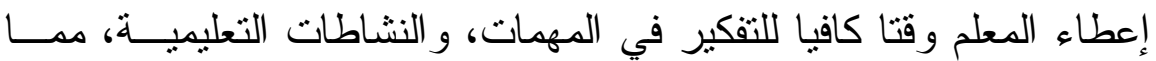
يحفز هم على المشاركة و التفكير و عدم التسر ع.

إعطاء الطلبة تغذية راجعة إيجابية بعيدا عـن الانتقــادات الجارحـة، أو التعليقات، وتشجيعهم على الاستمرار، توجيههم باستخدام الأسئلة المفتوحة و البحث عن إضافات أو بدائل جديدة. توظيف المنهج الدر اسي بما يخدم وينمي مهار ات التفكير الإبداعي. التتوع في التقويم بما يتتاسب وتتمية مهار ات التفكير العليا. ه - تنمية التفكير الإبداعي في الموضوعات القرائية تؤدي المدرسة دور ا مهمًا في التشجيع على الإبداع وتتميته، أو التتفير منه و إعاقته، فهي تقدم للمتعلم خبر ات منتوعة وشاملة ومتكاملة من خـــلال المــــهج المدرســي بمفهومة الو اسع، و المنهج الدر اسي باعتباره حياة المدرسة؛ يتيح الفرصـــة لحريــة التفكير و التحليل، وتوجيه الأسئلة و الاستفسار ات، كما يتيح الفرصة أمام المتعلمـين 


\section{العلد الحادي عشر .... الجزي الأول}

لغرس الثقة بالنفس، وروح المخاطرة في مو اصــلة البحــث و الاكتـشـاف. (حـسن شحاتة:أساسيات التدريس الفعال: • V (990، (199) و الإبداع في تدريس القر اعة يمكن أن يكون أداة فاعلة للإبداع في اللغة العربية، ومن ثم فإن حرص معلم اللغة العربية على القيام بممارسات تدريسية إبداعية، هو السبيل

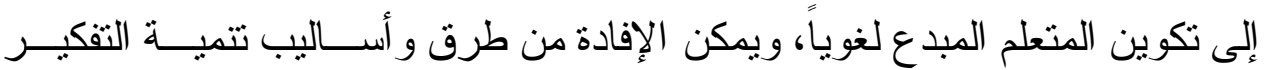
الإبداعي وتظويره داخل الصف، في تحديد منطلبات التدريس الإبداعي للغة العربية،

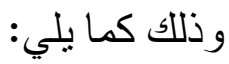

قبل التدرى: يخطط معلم اللغة العربية لأن يصبح المتعلمون قادرين على إصدار أكبر عدد ممكن من الكلمات، و الجمل، و الأفكار ، واســتبدال الكلمــات المعروفـــة، و الأفكار الروتينية بألفاظ جديدة، وتعبير ات غير تقليدية،وتقديم إضافات جديدة لكـلـل تعبير ، أو تكتب التفاعل مع المشكلات اللغوية، وتقديم حلول غير مألوفة و البحث عن معنى داخل الأساليب البلاغية غير المعني الظاهر . أثثاء التدرىس: يقوم معلم اللغة العربية بإنارة المناقشات، و إتاحة الفرصة للمـتـعلم للعب أدو ار متتوعة، وحثه على التخيل، ومطالبة المتعلمــين باســتخر اج كلمــات

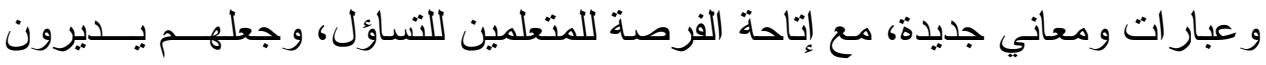

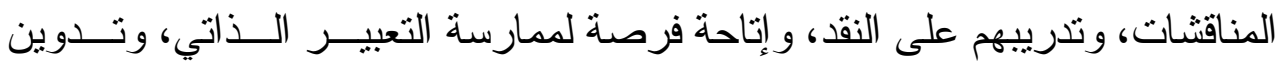

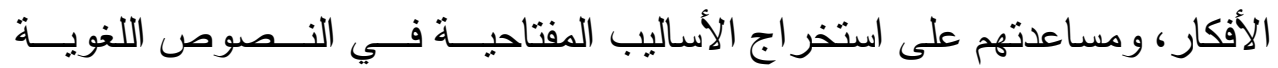
المختلفة، والتعرف علي المعاني الحقيقية و المجازية داخل الأساليب، وتحديد القر ائن و العلاقات بينها.

في نهایىة الحصة: تثري لغته وفكره، وتتمي تقكيره الإبداعي، وبالتــالي إيجــاد متعلم مبدع في لغته، وهذا التدريس الإبداعي للغة العربية مطلب تربوي، ولغــوي للحياة المعاصرة لذلك يجب الاهنمام بهذا النوع من المهار ات (محمد رجب فــض

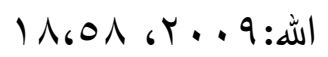




\section{نتائج البحث:}

استهدف هذا الجزء عرض النتائج التي توصل إليها البحث بعـد تطبيـق أدو اته، وفيما يلي بيان ذلك: أولاً: نتائج استبيان مهار ات التفكير الإبداعي:

تم تطبيق الاستبيان على مجموعة مكونة من (ع ب) أربعة وثثلاثين موجهــا من المتخصصين في اللغة العربية بالمرحلة الثانويــة، وتــم حـسـاب التكــرارات الأصلية المتوقعه لآر اء موجهي اللغة العربية - عينة البحث - في مهار ات التفكير الإبداعي لطلاب الصف الأول الثانوي العام، وكـذللك حسـساب النـسبة المئويـــة للتكر ار ات التي حظيت بها كل مفردة وكانت نتائج الاستبيان على النحو المبين في الجدول (1) - التحالى 
جدول (1)

\begin{tabular}{|c|c|c|c|c|c|c|c|}
\hline \multirow{2}{*}{ لالألرتيب } & \multirow[b]{2}{*}{ الوزن } & \multirow[b]{2}{*}{ الإحصائية)(الاية } & \multirow[b]{2}{*}{ كاr } & \multicolumn{3}{|c|}{ مناسبة بلرجة } & \multirow[b]{2}{*}{ المهارة(") } \\
\hline & & & & $\begin{array}{l}E^{*} \\
E^{*} \\
n^{\circ} .\end{array}$ & $\xi^{*}$ & 粱 & \\
\hline \multicolumn{8}{|c|}{ مهار ات التفكير الإبداعي } \\
\hline 7 & $\cdot, \wedge 7$ & - & $1 \cdot, 11$ & 7 & $\wedge$ & $r$. & 1 \\
\hline v & $\cdot, \wedge 7$ & - & $1 \cdot, 11$ & 7 & $\wedge$ & $r$. & r \\
\hline 1 & $\cdot, 99$ & $* *$ & Tr & - & 1 & سT & r \\
\hline r & $\cdot, 9 \Lambda \cdot r$ & $* *$ & 07,7 & . & r & r & $\varepsilon$ \\
\hline$\wedge$ & $\cdot, \vee \vee \leqslant$ & - & $r, .0$ & 17 & 1. & $\wedge$ & 0 \\
\hline 9 & $\cdot, V \cdot$ & - & Y I, $\varepsilon$ & $r \leq$ & 7 & $\varepsilon$ & 7 \\
\hline 1 . & $\cdot, 79$ & - & 10,17 & YI & 1. & $r$ & V \\
\hline 11 & $\cdot, \mathrm{V}$. & - & $11,0 \mathrm{r}$ & $r$. & 1. & $\varepsilon$ & $\wedge$ \\
\hline r & $\cdot, 9 \vee$ & $* *$ & 01,1 & 1 & r & M & 9 \\
\hline ir & $\cdot, T V$ & - & 07 & rr & 1 & 1 & 1 . \\
\hline Ir & • & - & $1 \cdot, \leqslant 7$ & M & $r$ & • & 11 \\
\hline$\varepsilon$ & $\cdot, 97$ & $* *$ & \&1, & 1 & $r$ & r. & ir \\
\hline $1 \varepsilon$ & $\cdot, 7071$ & - & $\varepsilon$ & rt & - & 1 & r \\
\hline 0 & $\cdot, 91$ & ** & $r \neg, \wedge \wedge$ & 1 & $\wedge$ & ro & $1 \varepsilon$ \\
\hline
\end{tabular}

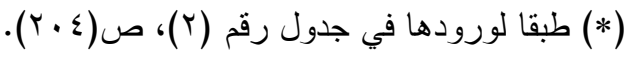

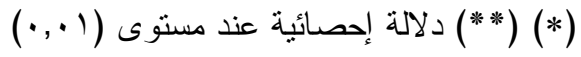

(-) عدم وجود دلالة إحصائية. 
تفسير النتائجج:

أولاً: إذا رجعنا إلى جدول (كا) 'َعندما درجة الحرية = درجنين عند نـسبة ه . , .

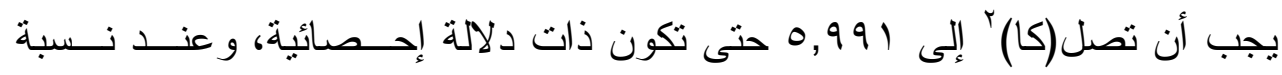

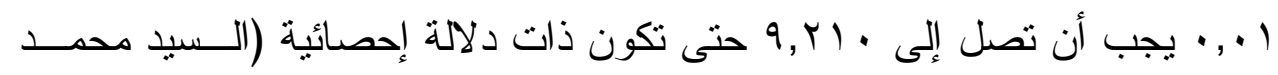

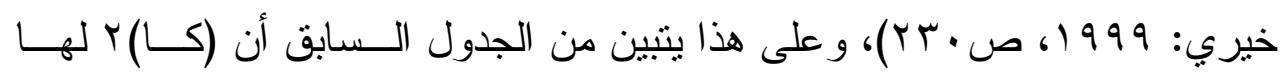
دلالة إحصائية للعبار ات الآتية:

- تحديد بعض المتر ادفات و المتضـادات المختلفة لمعنى كلمــة ورد ذكر هــــا فــي الموضو ع القر ائي. - تحديد أكثز من استخدام لكلمة معينة من النص. - تقديم أكبر عدد من الحلول المختلفة، لمشكلة وردت في الموضوع المقروء. - تحديد مشكلات أو عناصر ضعف في النص المقروء. - توظيف ما تمت ملاحظته، وكتابة تساؤ لات منبثقة عنها. ثانيا: اختبار مهارات التفكير الابداعي لطلاب المجموعتين: التجريبية الـضابطة قبليا 
جدول (r) (r)

قيمة (ت) ودلانتها الإحصائية للفرق بين متوسطى درجات طلاب المجموعة التجريبية و المجموعة الضابطة فى التطبيق القبلي لاختبار التفكير الابداعي فى كل مهارة من المهارات التى يقيسها الاختبار ككل.

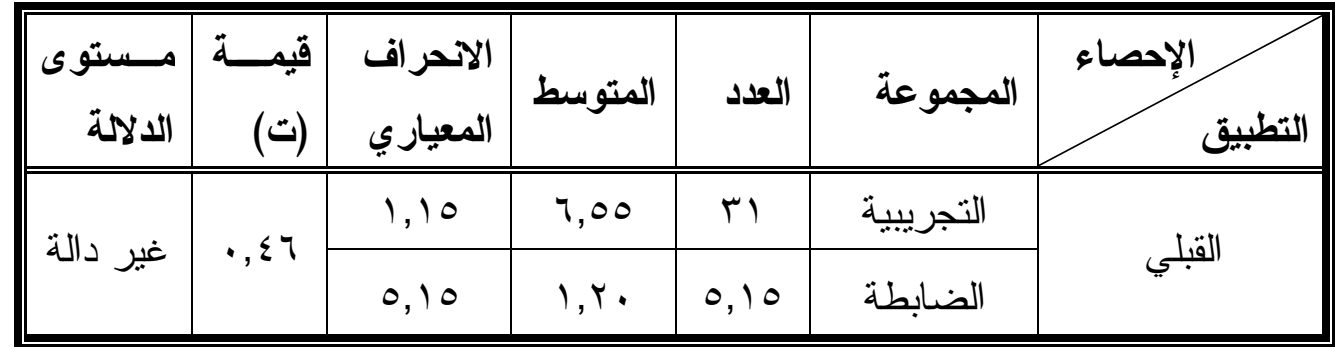

يتضح من الجدول السابق أن قيمة (ت) المحسوبة أقـلـل مــن قيمــة (ت)

الجدولية في المجموع الكلي للمهار ات، مما يدل على عدم وجود فــرق ذي دلالــــة إحصائية بين متوسطى درجات طلاب المجموعة التجريبية والمجموعة الــضابطة فى التطبيق القبلي لاختبار مهارات التفكير الابداعي، ولتفصيل قيمة (ت) ودلالتها الإحصائية للفرق بين متوسطى درجات طلاب المجموعة التجريبيــة و المجموعـة الضابطة فى التطبيق القبلي لاختبار مهارات التفكير الابداعي من خلال الجـدول الآتي:

جدول رقم (r) - (ب) - (ب)

\begin{tabular}{|c|c|c|c|c|c|c|}
\hline مستوى الدلالة & قيمة & الانحر اف & المتوسط & العدد & المجموعة & المهار ات \\
\hline \multirow{2}{*}{ غير دالة } & \multirow{2}{*}{$\cdot, 1 \leq$} & $1, r_{0}$ & 0,19 & M & التجرييية & \multirow{2}{*}{ الطلاقة } \\
\hline & & $\cdot, 0$. & $1, r q$ & r & الضـابطة & \\
\hline \multirow{2}{*}{ غير دالة } & \multirow{2}{*}{ • } & $\cdot, 0 \mathrm{~V}$ & $1, \leqslant 0$ & M & التجرييية & \multirow{2}{*}{ المرونة } \\
\hline & & $\cdot, 0 \mathrm{~V}$ & $1, \Sigma \wedge$ & rr & الضابطة & \\
\hline غير دالة &., 10 & $\cdot, \leqslant\rceil$ & $1, r q$ & r & التجرييية & الاصالة \\
\hline
\end{tabular}




\begin{tabular}{|c|c|c|c|c|c|c|}
\hline الدلالة & قيمة & الانحر اف المعياري & المتوسط & العدد & المجموعة & المهار ات \\
\hline & & $\cdot, \leqslant 0$ & $1, Y V$ & سז & الضابطة & \\
\hline \multirow{2}{*}{ غير دالة } & \multirow{2}{*}{$\cdot, \cdots$} & $\cdot, 0 Y$ & $1, \ldots$ & r & التجرييية & \multirow{2}{*}{ الحشكاسية } \\
\hline & & $\cdot, 0$. & $1, \cdots$ & זr & الضابطة & \\
\hline \multirow{2}{*}{ غير دالة } & \multirow{2}{*}{$\cdot, 1 \leqslant$} & $1, Y_{0}$ & 0,19 & T & التجريبية & \multirow{2}{*}{ المجموع } \\
\hline & & $1, r$. & 0,10 & سז & الضابطة & \\
\hline
\end{tabular}

يتضـح من الجدول السابق أن قيمة (ت) المحسوبة أقـلـل مــن قيمــة (ت) الجدولية في كل مهارة من المهار ات و المجموع الكلي لها، مما يــدل علــى عــدم وجود فرق ذي دلالة إحصائية بين متوسطى درجات طلاب المجموعة التجريبيـة والمجموعة الضابطة فى التطبيق القبلي لاختبار التفكير الابداعي فى كل مهــارة

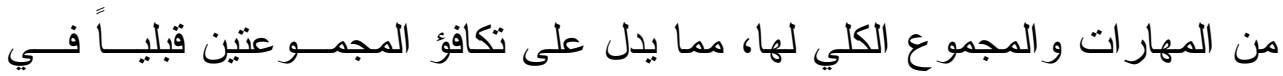
مهار ات التفكير الابداعي.

ثالثًا: اختبار الفرض الثاني: ينص الفرض الثاني من فروض البحث على ما يأتي:

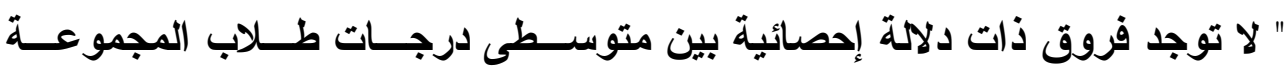
التجريبية فى التطبيقين القبلى والبعدى لاختبار مهارات التفكير الابداعي " للتحقق من صحة هذا الفرض قام الباحث بحساب قيمة (ت) للمقارنة بين متوسطى درجات طلاب المجموعة التجريبية فى التطبيقين القبلى والبعدى لاختبار مهارات التفكيـر الابداعي، ويتضح ذلك من الجدول التالي: 
جدول (๕)

قيمة (ت) ودلانتها الإحصائية للفرق بين متوسطى درجات طلاب المجموعة التجريبية فى التطبيقين القبلى والبعدى لاختبار التفكير الابداعي ككل

\begin{tabular}{|c|c|c|c|c|c|c|c|c|c|}
\hline \multirow{2}{*}{ | التأثير } & \multirow{2}{*}{ الإحصائية } & \multirow{2}{*}{ قيمة المحسوبة } & \multicolumn{2}{|c|}{ قيمة (ت) } & \multirow{2}{*}{ الحرية } & \multirow{2}{*}{ الاتحر افياري } & \multirow{2}{*}{ الحستوسطي } & \multirow{2}{*}{ العدد } & \multirow[t]{2}{*}{ لإحهريائية } \\
\hline & & & $\cdot, \cdot 1$ &,, .0 & & & & & \\
\hline \multirow{2}{*}{$r v, 17$} & \multirow{2}{*}{$\cdot, \cdot 1$} & \multirow{2}{*}{$70,0 \leqslant$} & \multirow{2}{*}{ r, Yo } & \multirow{2}{*}{$r, \cdot \varepsilon$} & \multirow{2}{*}{$r}$. & $1, r_{0}$ & 0,19 & ו & القبلي \\
\hline & & & & & & I, & $r v, \cdot r$ & M & البعدي \\
\hline
\end{tabular}

يتضح من الجدول السابق أن قيمة (ت) المحسسوبة (10,0 7) وقيمسة (ت)

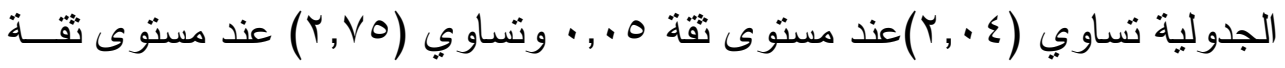

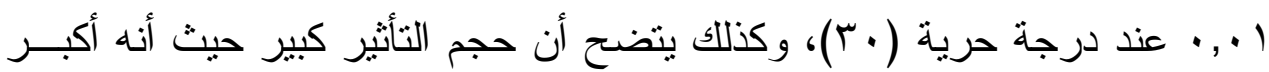

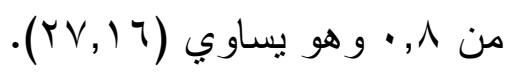

مما سبق يتضـح أن قيمة (ت) المحسوبة أكبر من قيمة (ت) الجدوليـــة ممـــا يدل على وجود فرق ذو دلالة إحصائية لصالح التطبيق البعدي. وبذللك تم التحقـق

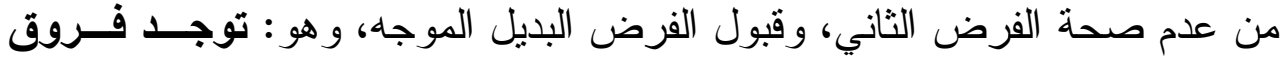
ذات دلالة إحصائية بين متوسطى درجــات طــلاب المجموعــة التجريبيــة فــى التطبيقين القبلى والبعدى لاختبار مهار ات التفكيـر الابـــاعي لــصالح التطبيـق البعدى، ولقد قام الباحث بحساب قيمة (ت) للمقارنة بين متوسطى درجات طــلاب المجموعة التجريبية فى التطبيقين القبلى والبعدى لاختبار التفكير الابداعي فى كل مهارة من المهار ات التى يقيسها. كما يلي: 


\section{جدول (0)}

قيمة (ت) ودلالتها الإحصائية للفرق بين متوسطى درجات طلاب المجموعة التجريبية فى التطبيقين القبلى والبعدى لاختبار مهارات التفكير الابداعي فى كل بعد من الابعاد التى يقيسها الاختبار

\begin{tabular}{|c|c|c|c|c|c|c|c|}
\hline $\begin{array}{c}\text { حجم التأثير } \\
\text { (d) }\end{array}$ & مستوى الدلالة & 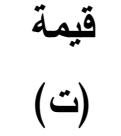 & الانحر اف المعياري & المتوسط & العدد & التطبيق & الابعاد \\
\hline \multirow{2}{*}{$17, \wedge r$} & \multirow{2}{*}{$\cdot, \cdot 1$} & \multirow{2}{*}{$\leqslant 7,00$} & $\cdot, 01$ & $1, \leqslant 0$ & M & القبلى & \multirow{2}{*}{ الطلاقة } \\
\hline & & & $\cdot, V$. & 1,19 & M & البعدي & \\
\hline \multirow{2}{*}{$1 \leqslant, V V$} & \multirow{2}{*}{$\cdot, \cdot 1$} & \multirow{2}{*}{$\varepsilon \cdot, \leqslant 0$} & $\cdot, 0 \mathrm{~V}$ & $1, \leqslant 0$ & M & القبلى & \multirow{2}{*}{ المرونة } \\
\hline & & & $\cdot, \vee$. & $\wedge, 1$. & ו & البعدي & \\
\hline \multirow{2}{*}{$1 Y, V q$} & \multirow{2}{*}{$\cdot, \cdot 1$} & \multirow{2}{*}{$r_{0, \cdot \varepsilon}$} & $\cdot, \leq 7$ & $1, r q$ & ו & القبلى & \multirow{2}{*}{ الاصالة } \\
\hline & & & $\cdot, V Y$ & $0, r q$ & M & البعدي & \\
\hline \multirow{2}{*}{$9, \Gamma_{1}$} & \multirow{2}{*}{$\cdot, \cdot 1$} & \multirow{2}{*}{$r 0,01$} & . or & $1, \ldots$ & ו & القبلى & \multirow{2}{*}{ الحسكاسية } \\
\hline & & & $\cdot, \times 1$ & $0, r_{0}$ & $\mu_{1}$ & البعدي & \\
\hline
\end{tabular}

يتضـح من الجدول السابق أن قيمة (ت) المحسوبة أكبــر مــن قيمــة (ت) الجدولية عند مستوى دلالة ( ( . . )، وكذلك يتضـح أن حجم التأثير كبير حيث أنــه أكبر من (^, •) في كل بعد من الابعاد و المجموع الكلي. مما بدل على وجود فرق ذي دلالة إحصائية بين متوسطى درجات طلاب المجموعة التجريبية فى التطبيقين القبلى والبعدى لاختبار مهارات التفكير الابداعي فى كل بعد من الابعاد و المجموع الكلي لصالح التطبيق البعدي. 


\section{العلد الحادي عشر .... الجزي الأول}

ثالثا: اختبار الفرض الثالث: بالنسبة للفرض الثالث من فروض البحث و الذي ينص على ما يلي: " لاتوجد فروق ذات دلامة إحصائية بين متوســطى درجــات طــلاب المجموعة التجريبية والمجموعة الضابطة فى التطبيق البعدي لاختبــار التفكيـر الابداعي "للتحقق من صحة هذا الفرض قام الباحث بحساب قيمة (ت) للمقارنة بين متوسطى درجات طلاب المجموعة التجريبية والمجموعة الضابطة فـى التطبيـق البعدي لاختبار مهارات التفكير الابداعي، ويتضح ذلك من الجدول التالي:

جدول (7)

قيمة (ت) ودلاتها الإحصائية للفرق بين متوسطى درجات طلاب المجموعة التجريبية والمجموعة الضابطة فى التطبيق البعدي لاختبار التفكير الابداعي ككل

\begin{tabular}{|c|c|c|c|c|c|c|c|c|c|}
\hline \multirow{2}{*}{$\begin{array}{l}\text { التأثير } \\
\text { (d) }\end{array}$} & \multirow{2}{*}{ الإحصائية } & \multirow{2}{*}{ قالمحسوبة) } & \multicolumn{2}{|c|}{ قيمة (ت) } & \multirow{2}{*}{ الحرية } & \multirow{2}{*}{ الآحر افياري } & \multirow{2}{*}{ (الحستوسطي } & \multirow{2}{*}{ (ن) } & \\
\hline & & & $\cdot, \cdot 1$ & $\cdot, \cdot 0$ & & & & & \\
\hline \multirow{2}{*}{$r, \varepsilon\rceil$} & \multirow{2}{*}{$\cdot, \cdot 1$} & \multirow{2}{*}{$9,{ }^{9}$} & \multirow{2}{*}{$r, 77$} & \multirow{2}{*}{$r, \ldots$} & \multirow{2}{*}{$7 r$} & מזr & $r v, \cdot r$ & M & التجريبية \\
\hline & & & & & & ק & $r Y, \leqslant 0$ & rr & الضـابطة \\
\hline
\end{tabular}

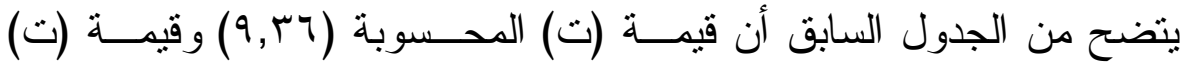

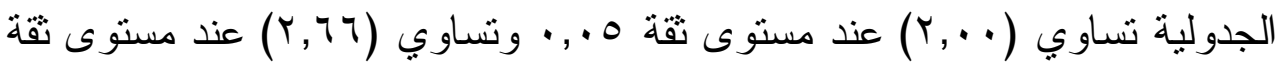
I. , • عند درجة حرية (YT)، ومعنى ذللك أن المجموعة التجريبية فــي الاختبــار البعدي كانت قد نمت لديهم مهار ات التفكير الإبداعي عما كانت عليه في الاختبــار

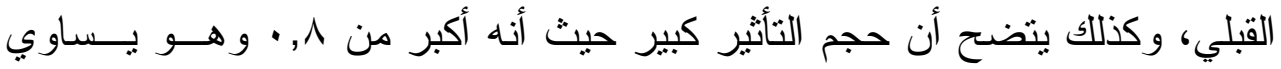
(Y, ؟ (Y)، مما سبق يتضح أن قيمة (ت) المحسوبة أكبر من قيمة (ت) الجدولية مما يدل على وجود فرق ذو دلالة إحصائية لصالح المجموعة التجريبية. وبــللك تـــ التحقق من عدم صحة الفرض السادس، وقبول الفرض البديل الموجه، وهو: 
توجد فروق ذات دلالة إحصائية بين متوسطى درجات طــلاب المجموعــة التجريبية و المجموعة الضابطة فى التطبيق البعدي لاختبار التفكير الابداعي لصالح المجموعة التجريبية، ولقد قام الباحث بحساب قيمة (ت) للمقارنة بــين متوســطى درجات طلاب المجموعة التجريبية و المجموعة الضـبطة فـى التطبيـق البعــي لاختبار التفكير الابداعي فى كل مهارة من المهار ات التى يقيسها كما يلي:

\section{جدول جد)}

قيمة (ت) ودلاتها الإحصائية للفرق بين متوسطى درجات طلاب المجموعة التجريبية و المجموعة الضابطة فى التطبيق البعدي لاختبار التفكير الابداعي فى كل بعد من الابعاد

التى يقيسها الاختبار

\begin{tabular}{|c|c|c|c|c|c|c|c|}
\hline $\begin{array}{c}\text { التأثثير } \\
\text { (d) } \\
\end{array}$ & مستوى الدلالة & قيمة & الالحر اف & |المتوسط & العدد & |المجموعة & الابعاد \\
\hline \multirow{2}{*}{1,79} & \multirow{2}{*}{$\cdot, \cdot 1$} & \multirow{2}{*}{7,77} & $\cdot, \mathrm{V}$. & 1,19 & r & التجريبية & \multirow{2}{*}{ الطلاقة } \\
\hline & & & $1, r_{0}$ & $7,0 Y$ & سr & الضـابطة & \\
\hline \multirow{2}{*}{$\cdot, \wedge$. } & \multirow{2}{*}{$\cdot, \cdot 1$} & \multirow{2}{*}{$r, 17$} & $\cdot, V \cdot$ & $\wedge, 1$. & M & التجريبية & \multirow{2}{*}{ المرونة } \\
\hline & & & $\cdot, 9 \vee$ & $V, \varepsilon r$ & rr & الضابطة & \\
\hline \multirow{2}{*}{1,00} & \multirow{2}{*}{$\cdot, \cdot 1$} & \multirow{2}{*}{$7, .9$} & $\cdot, V Y$ & $0, r q$ & r & |التجريبية & \multirow{2}{*}{ الاصالة } \\
\hline & & & •, 94 & $\varepsilon, 1\}$ & rr & |لضابطة & \\
\hline \multirow{2}{*}{$1, r$} & \multirow{2}{*}{$\cdot, \cdot 1$} & \multirow{2}{*}{$0,1 Y$} & $\cdot, V_{1}$ & $0, \mu_{0}$ & M & التجرييية & \multirow{2}{*}{ للمشكاسبة الحست } \\
\hline & & & $\cdot, \vee \vee q$ & $\varepsilon, \Gamma q$ & Tr & الضابطة & \\
\hline
\end{tabular}

يتضـح من الجدول السابق أن قيمة (ت) المحسوبة أكبـر مــن قيمــة (ت)

الجدولية عند مستوى دلالة ( ( . , )، وكذلك يتضح أن حجم التأثير كبير حيث أنــهـ أكبر من أو يساوى (^, • ) في كل بعد من الابعاد و المجموع الكلي،مما يدل علـىى 


\section{العدد الحادي عشر ... الجزئ الأول}

وجود فرق ذي دلالة إحصائية بين متوسطى درجات طلاب المجموعة التجريبيـة والمجموعة الضابطة فى التطبيق البعدي لاختبار التفكير الابداعي فى كل بعد من الابعاد و المجموع الكلي لصالح المجمو عة التجريبية. التوصبات و المقترحات:

في ضو ء نتائج البحث يتقدم الباحث ببعض التوصيات و المقترحات التي يرى أنها تفيد عند تتمية التفكير الإبداعي باسـتخدام إبــتر اتيجية المناقـشة فـي تــدريس

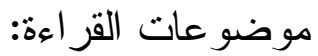

- العناية بتقويم الأداء القرائي للطلاب باســتخدام اختبــار ات مخصــصة لهــذا الغرض، ويمكن الاسترشاد - في إعدادها- باختبار مهار ات التفكير الإبــداعي

$$
\text { الذي قدمه البحث الحالي. }
$$

- - ضرورة إعداد دليل للمعلم يساعده في تتمية مهار ات التفكير الإبداعي المختلفــة لاى طلابه في مر احل التعليم العام ويمكن الاسترشاد -في إعداده- بدليل المعلم الذي قدمه البحث الحالي.

- تشجيع الطالب على تحليل ونقد ما يقر أ، و عدم قبوله للاروس المقرو عة لمجــرد

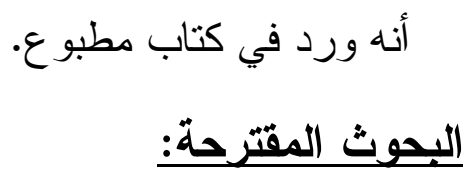

في ضوء ما أسفرت عنه نتائج البحث، وفي ضوء التوصــيات الــسابقة يقتـر ح

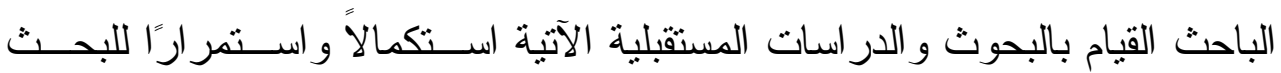
الحالي. 
- أثز استخدام استر اتيجية المناقتنة في تتمية مهار ات التفكير الإبداعي في النصوص الثعرية. - أثز دمج بعض استر اتيجيات المناقتنة في تدريس موضوعات النحو المختلفة. - أثز استخدام استز اتيجية المناقشة في تتمية مهار ات التفكير العليــا فــي تــدريس البلاغة لدى طلاب الصف الأول الثانوي العام.

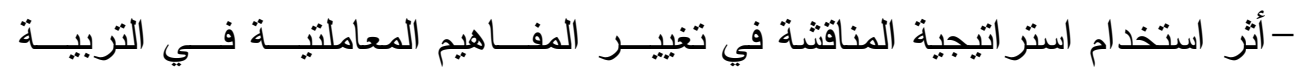
الإسلامية لطلاب الصف الأول التثانوي 


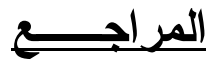

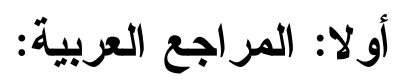

إير اهيم محمد عطا: المرجع في تلدريس اللغة العربية، القاهرة: مركــز الكتــاب،

$$
. r .0
$$

أحمد حسين اللقاني و علي الجمل:معحم المصطلحات التربوية المعرفة في المناهج

$$
\text { وطرق التّريس، القاهرة: عالم الكتب، (r . . r) م. }
$$

أحمد البلولة إزيرق فريحة، الثفاء عبد القادر علي: "إستر اتيجية تعلــيم مهــار ات التفكير و أثرها في تتمية التفكير الإبداعي في اللغة العربيــة (بمحليــة أم

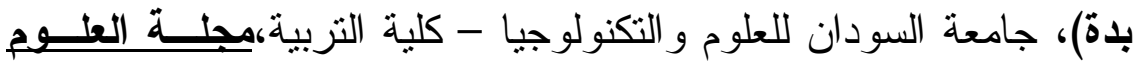

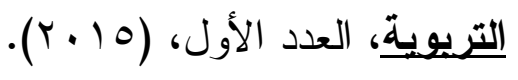

أحمد محمد المعتوق: الحصبلة اللغوية: أهميتهــا، مــصادر، وســائل تنميتهـــا،

$$
\text { الكويت: عالم المعرفة، العدد (Y Y Y)، أغسطس } 997 \text { (م. }
$$

أحمد يوسف عبدالعزيز :" تتمية كفايات الإبداع لدى طلاب شعبة الجغر افيــا بكليـــة التربية بسو هاج"، رسالة دكتور اه كلية التربية،جامعة سوهاج،(7 999 ())، أسماء محمد محروس حسن:" فاعلية برنامسج في تدريس البلاغة قائم على بعـض

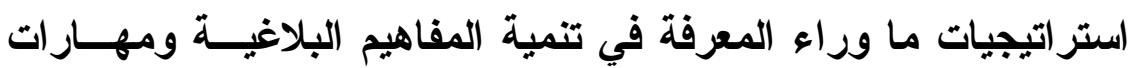
التذوق الأدبي لاى طلاب الصف الأول الثانوي" رسالة ماجستير، كليــة

$$
\text { التزبية جامعة المنيا،(ع ( ب). }
$$

أثجان حامد الثديفات: برنامج تعليمي قائم على استر اتيجية دوائر الأدب والكثف

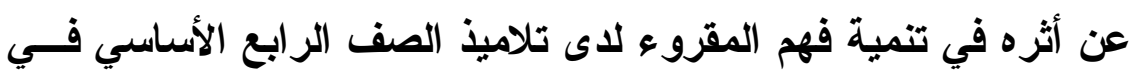


الأردن." مجلة الجامعــة الإســلامبة للار اســات التزبويسـة و النفـسبة،

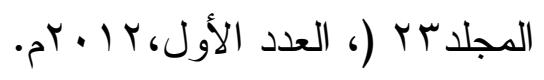

أماني محمد عبده الديب: "قاعليــة برنـامج قائم على التـــريس التأملي في تنمية مهارات التذوق الأدبي والتفكير الإبداعي لاى تلاميذ المرحلة الابتدائيــة

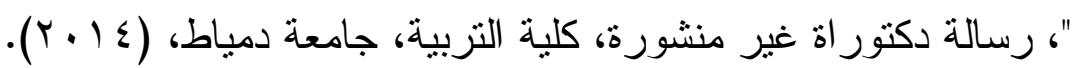

السيد محمد خبري: الإحصاء في البحوث التربوية، القاهرة: دار الفكــر العربـي، .0 .1999

إنشر اح إير اهيم محمد المشرفي: " فاعلية برنامج مقترح لتنمية كفايات تعليم التفكير الإبداعي لاى الطالبات المعلمات بكلية رياض الأطفال،رسالة دكتـور اة،

$$
\text { كلية التربية جامعة الأسكندرية،(ب . . r)م. }
$$

بسام عبد الله طه إبر اهيم: " التعلم المبني على المشكلات الحباتية وتنمبة التفكبـر

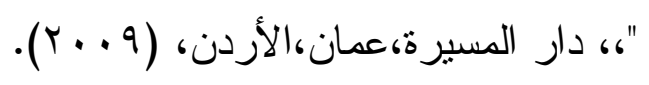

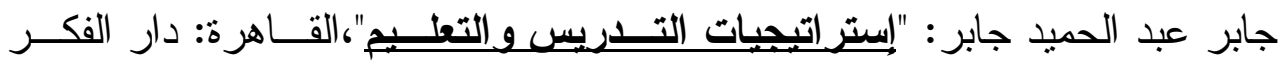

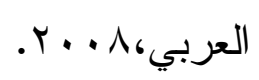

جودت أحمد سعادة: تدريس مهارات التقكير"، عمان، دار الثروق،(0 . . ب)م. حسن حسين زيتون: استر اتيجيات التدريس: رؤية معاصرة لطرق التعليم و الــتعلم،

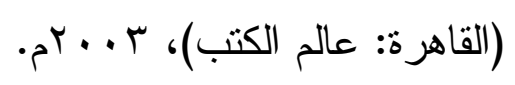

: تعليم التفكير رؤية تطبيقية في تتمية العقول المفكرة، (القــاهرة:

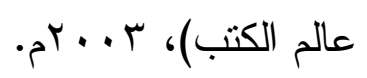

وكمال عبد الحميد زيتون: التعلم و التثريس من منظور النظريــة

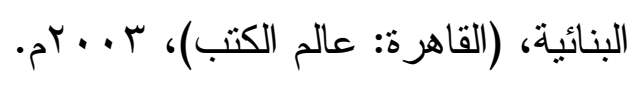




\section{العلد الحادي عشر .... الجزي الأول}

حسن سيد شحاته: تعليم اللغة العربية بين النظرية و التطبيق، طه، (القاهرة: الــدار المصرية اللبنانية)، r ب. . بم.

وزينب النجار : معجم المصطلحات التربويــة و النفــسية، (القـــاهرة:

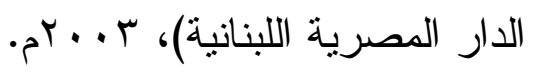

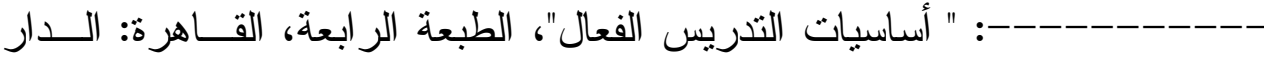

$$
\text { المصرية اللبنانية، ع + . rم. }
$$

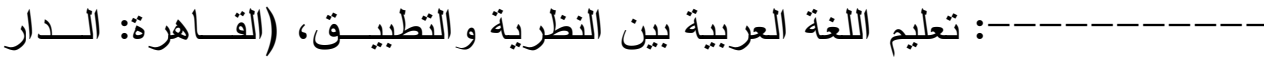
المصرية اللبنانية)، الطبعة الخامسة، r . . F م.

:- إستر اتيجيات التعليم و التعلم الحديثة وصناعة العقـلـل العربــي، (القاهرة: الدار المصرية اللبنانية)، الطبعة الأولى، يناير ^ ـ. . .

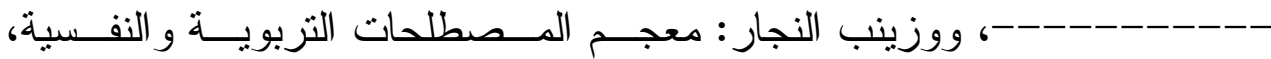

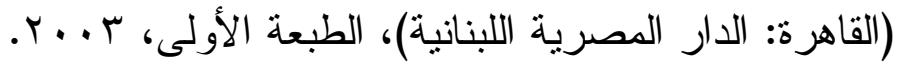

سيد السايح حمدان: "استخدام أسلوب العصف الذهني في تدريس البلاغــة وأثـــره

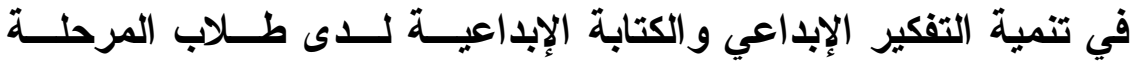
الثانوية"، الجمعية المصرية للمناهج وطرق التدريس، المؤتمر العلمـي الخامس عشر ، مناهج التعليم و الإعداد للحياة المعاصرة، جr، ب +. rم.

سيد أحمد عثمان: " التخطيط اللفوي وتعليم اللغة العريبــة " دراســات تريويـــة، المجلد الأول، الجزء الر ابع، القاهرة: عالم الكتب، 919 ام.

صفاء يوسف الأعصر : تعليم من أجل التفكير، (القاهرة: دار قباء)، 991 . صلاح الدين عرفة محمود: "تفكير بلا حدود، رؤى تريوية معاصــرة فـي تعلـيِي التقكير وتعلمه"، (القاهرة، عالم الكتب، ج + . Yم). 
صلاح فضل: "الأساليب الثعرية المعاصرة"، بيروت، دار الآداب، (910 ( ) عبد الرحمن كامل عبد الرحمن: مهارت التفكير اللازمة لتدريس النحـو ومـــى توافرها لاى الطلاب المعلمين في كيفية إكسابها إياها، وأثرهـــا علــى تحصيل طلاب الصف الأول الثانوي العام، المؤتمر العلمى الثالث، التربية

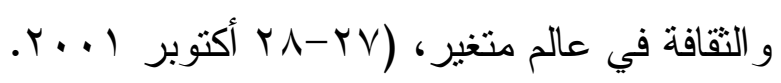

عبد القادر الثيخلي ( ( . ؟ ):" تنمية التفكير الإبداعي"، عمان: وزارة الثباب. عبد الله النافع: "إستر اتيجيات تعليم مهارات التفكير العليا ضمن المواد الاراســية" ضمن ورشة العمل الخاصة بالتعليم المعتمد على التفكير (الرياض، النافع

$$
\text { للبحوث و الاستشار ات التعليمية،(r . . rم). }
$$

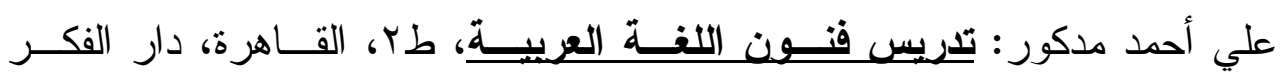

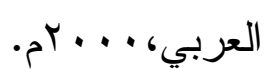

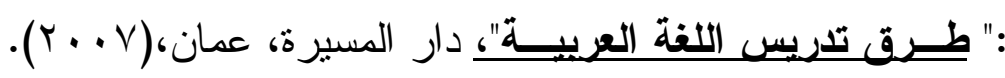

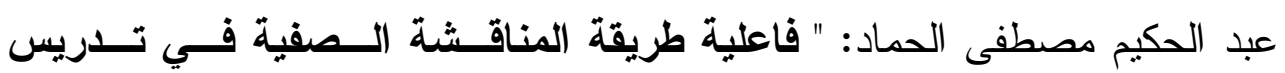
الجغر افيا "، رسالة ماجستير غير منشورة، كلية التربية، جامعة دمـشق،

$$
\text { - }) 991
$$

عبد الرازق مختار محمود: " أثز استخدام أسلوب القدح الذهني في تتمية مهــار ات القر اعة الإبداعية لدى تلاميذ المرحلة الابتدائية "، مجلة البحث في التربية

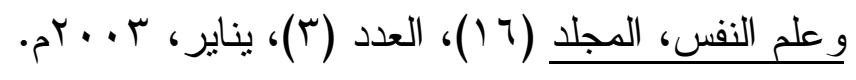

علي أحمد مدكور : " طريقة المناقثة وأهميتها في تعليم الكبار"، مجلـــة التزبيـــة

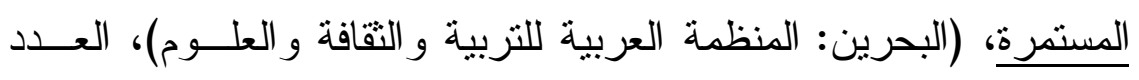

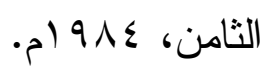




\section{العلد الحادي عشر .... الجزي الأول}

فاضل خليل إبر اهيم: " أثز طريقة المناقنشة بأسلوب المجموعــات الــصغيرة فـي

تحصيل المعرفة و الاحتفاظ بها لدى طلبــة العلـــوم الاجتماعيــة بكليـــة

المعلمين جامعة الموصل "، مجلة مركز البحوث التزبوية، جامعة قطــر ،

العدد الخامس عشر، يناير 999 (م.

فتحي علي يونس: اسنر اتيجيات تعليم اللغة العربية في المرحلة الثانوية، (القــاهرة: مطبعة الكتاب الحديث)، ، . . بوم.

هند توفيق الأسطل: "مهار ات التفكير الإبداعي المتضمنة في محتوى منهـــاج الأدب و النصوص للصف الحادي عشر ومدى اكتساب الطلبــة لهــا". رســالة ماجستير، كلية التزبية- الجامعة الإسلامية بغزة، 1 . . بام.

هيفاء حميد حسن: "فعالية تدريس نظرية TRIZ في الأداء التعبيري وتتمية التفكير الإبداعي لاى طلاب المرحلة الإعدادية"،جامعة ديالي،العراق، مجلة كلية

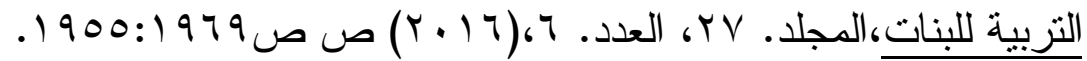

وليد بن طر اد الثمري: "أثز استخدام استر اتيجية القراءة الحرة الموجهة في تحسين بعض مهار ات التفكير الإبداعي لاى طلاب الصف الثالث المتوسط فـي المملكة العربيــة الـسعودية"، رســالة ماجسـتير، كلية التربية،جامعــة اليرموك، المملكة العربية السعودية، ( / • Y)م.

\section{ثانيا المراجع الإنجليزية:}

Abdelrahman Kamal: Using Computers in the Programming of Qualifying Teachers of Arabic in the Faculties of Education in Egypt" Available At: http://www.eric.ed.gov. (ED466180) (2001). 
-:" Improving the quality of student learning"،

International Journal of Innovation and Scientific

Research، ISSN 2351-8014 Vol. 2 No. 1 Jun. Innovative

Space of Scientific Research Journals ‘2014.

Angeli, Charoula, Valanides Nicos: Instructional Effects on Critical Thinking: Perfmance on Ill-Defined Issues, Journal Articles, Learning and Instruction ,V19n4,p322-334,Aug,2009.

http://www.eric.ed,gov.eric.Ej833378. Available at:

Appleton, K:Analysis and Description of Students Learning during Science Classes using constructivist Based Model, Journal of Research in Science Teaching, Vol. 34, No. 3(1997).

Arthur Costa: Components of a well Developed Thinking Skills Program, U.S.A. , New Horizons for learning: Teaching and Learning Strategies, October 2002. (http: // www. $\underline{\text { New horizons. org / html) }}$

Carter، M.: "Training Teachers For Creative Learning Experiences" Child Care Information Exchange. No. 85. May- Jan،(1992).p42.

Clark، J. Elizabeth Hiraldo، Carlos: Rates of exchange: team teaching a latiola literature course from two theoretical views. (U. S. A: Radical teacher: June، 2004 
Ferrer، Erica; Staley، Kendra: Designing an EFL Reading Program to Promote Literacy Skills، Critical Thinking، and Creativity، CATESOL Journal، v28 n2 p79-104 2016.

Available At: www.ERIC،No.(J1119613).

And look for: - Rosenblum - cale، Karen: Teaching Thinking Skills: Does it Improve creativity? Gifted - Child - Today (GCT) Vll NZ،(1987)‘p.p44-47.

R. J. Sternberg (Ed.)، The nature of creativity (pp.148-176). New York: The Press Syndicate of the University of Cambridge. 